\title{
Political Dynasties and the Selection of Cabinet Ministers*
}

\author{
Daniel M. Smith ${ }^{\dagger} \quad$ Shane Martin ${ }^{\ddagger}$
}

May 16, 2016

\begin{abstract}
We investigate whether politicians whose family relatives previously served in parliament and cabinet enjoy a competitive "legacy advantage" in progressing from the backbenches to cabinet. This advantage may stem from two potential mechanisms: a direct effect attributable to the informational advantages of legacies, or an indirect effect that operates through greater electoral strength. We evaluate the relative contribution of each mechanism using candidatelevel data from Irish parliamentary elections and cabinets from 1944-2016. Our results reveal that politicians with a family history in cabinet do enjoy an advantage in cabinet selection, and that this advantage cannot be attributed simply to greater electoral popularity.
\end{abstract}

Keywords: political dynasties, ministerial selection, Ireland

Word count: 9,156 (excluding references and online appendix)

${ }^{*}$ We thank Mark Daley, Anna Gomez, Max Goplerud, Darragh Nolan, and Aaron Roper for research assistance, and Matt Blackwell, Gary Cox, Jon Fiva, Simo Goshev, Torben Iversen, Horacio Larreguy, Phillip Lipscy, Kenneth McElwain, Benjamin Nyblade, Dustin Tingley, David Willumsen, Ista Zahn, and Christopher Kam and three anonymous reviewers for helpful comments.

${ }^{\dagger}$ Assistant Professor, Department of Government, Harvard University. Email: danielmsmith@ fas.harvard.edu (Corresponding author).

${ }^{*}$ Reader in Comparative Politics, Department of Government, University of Essex. E-mail: shane.martin@essex.ac.uk. 
Under parliamentarism, the cabinet "emerges from" the legislature and represents the apex of political power. Scholars have thus long sought to understand which political parties win cabinet seats, particularly in coalition governments, as the interparty distribution of ministerial portfolios can impact policy outputs (Laver and Schofield, 1998; Strøm, Müller and Bergman, 2003; Bäck, Debus and Dumont, 2011). Yet cabinets are ultimately composed of individual politicians within parties. Despite this fact, and the potential for significant individual ministerial autonomy and discretion (Laver and Shepsle, 1994, 1996), we know relatively little about the intraparty distribution of ministerial portfolios.

Multiple factors may be involved in determining how positions of power are distributed to members of parliament (MPs). All parties and legislatures, like most organizations generally, are structured according to some form of hierarchy, such that some MPs are promoted to a finite number of positions of power in the party, parliament, and government, while others continue to warm the backbenches, sometimes for their entire careers (Strøm, 1997). Existing research suggests that the probability of promotion to cabinet is related to an MP's length of time in parliament (seniority), electoral popularity (in preferential electoral systems), education, gender, policy preferences, and other less-tangible personal traits (e.g., Blondel and Thiébault, 1991; Laver and Shepsle, 1994; Dowding and Dumont, 2008, 2013). 1

In this study, we consider one previously unexplored source of potential inequality of opportunity in ministerial selection: the existence of powerful family dynasties within parties. Dynasties are common in many democracies, and tend to enjoy significant electoral advantages over other candidates under electoral systems with candidate-based voting (e.g., Laband and Lentz, 1985; Ishibashi and Reed, 1992; Dal Bó, Dal Bó and Snyder, 2009; Feinstein, 2010; Smith, 2012; Asako et al., 2015; Querubin, 2016). The existing literature attributes this electoral advantage primarily to the informational cue that family "brand" or name recognition has on voters. Building

\footnotetext{
${ }^{1}$ In the next section, we provide a more complete review of the literature on ministerial selection, which has expanded considerably in recent years. Recent studies on the de-selection of ministers include Huber and MartinezGallardo (2008), Dewan and Myatt (2010), Berlinski, Dewan and Dowding (2010), Fischer, Dowding and Dumont (2012), and Indridason and Kam (2008).
} 
on this literature, we investigate whether and how MPs who come from such dynasties, who we call "legacies," also possess advantages over non-legacies in promotion from the backbench to the cabinet. $2^{2}$

Anecdotal evidence of a legacy advantage in cabinet selection is abundant. For example, Canadian Prime Minister Justin Trudeau, son of former Prime Minister Pierre Trudeau, reached the apex of power in 2015 at age 43 - after only serving two previous terms in the House of Commons. In 2008, Yuko Obuchi, daughter of former Japanese Prime Minister Keizo Obuchi, was similarly appointed to cabinet in her third term, at the age of 34. Most Japanese MPs are not considered for a cabinet position until at least five or six terms. In Norway, former Prime Minister Jens Stoltenberg, son of Minister of Defense and Minister of Foreign Affairs Thorvald Stoltenberg, had only served two years as a substitute member in the Storting (parliament) before being appointed to cabinet in his first full term in 1993, at the age of 34. A brief glance at recent presidential politics in the United States also suggests a legacy advantage in executive politics outside of parliamentary regimes - the 2016 presidential primary featured a Clinton, a Bush, and a Paul; all familiar names from previous contests ${ }^{3}$

A legacy advantage in cabinet selection, we hypothesize, may result from two potential mechanisms. The first can be considered a direct effect of dynastic ties that includes the intergenerational transmission of political knowledge, connections, and resources, as well as the informational cue of family name and reputation to party leaders involved in ministerial selection. For simplicity, we call this the informational advantage. The second potential mechanism is an indirect, mediating effect of dynastic ties that operates through the greater electoral strength of

\footnotetext{
${ }^{2}$ Specifically, we define a legacy as any candidate who is related by blood or marriage (e.g., child, grandchild, sibling, spouse, son-in-law, or other such relative) to a politician formerly or currently holding national office (including cabinet positions) who served prior to the first election of the candidate. If a legacy is elected, he or she creates a dynasty, which we define as any family in which two or more members served non-concurrently in national office. In other words, if two family members are first elected in the same election, or are married after being elected, then neither counts as a legacy, and the two do not constitute a dynasty.

${ }^{3}$ According to a working paper by Besley and Reynal-Querol (2015), 15-20 percent of political executives crossnationally have been legacies since the 1990s.
} 
legacies. We call this the electoral advantage.

We distinguish between two types of legacies among MPs: cabinet legacies whose predecessors had experience as cabinet ministers; and non-cabinet legacies whose predecessors never advanced beyond the backbenches. We argue that, while both types of legacies may enjoy significant electoral advantages in their districts, cabinet legacies should be expected to enjoy a larger intraparty informational advantage over fellow MPs in gaining promotion from the backbenches to the cabinet. This is because cabinet legacies inherit the knowledge, political resources, high-level connections, and family track record in cabinet that helps them to stand out above their co-partisan peers in ministerial selection. In contrast, legacies whose relatives did not serve in the cabinet may inherit the knowledge, connections, and name recognition to be successful electorally in their districts, but this knowledge does not necessarily provide the same informational advantage in terms of leadership promotion within the party. As such, cabinet legacies can be expected to reach ministerial office faster than both non-cabinet legacies and non-legacies.

We test our prediction that cabinet legacies are advantaged relative to other MPs in advancement from the backbenches to cabinet with new candidate-level data from Irish parliamentary elections and cabinets from 1944-2016. Members of the Irish Dáil (the lower and more important chamber of the bicameral Houses of the Oireachtas) are known as Teachtaí Dála (TDs), and are elected via the single-transferable vote (STV) electoral system in multi-member districts, with an average district magnitude $(\mathrm{M})$ of four seats ${ }_{5}^{5}$ In such a system, district races usually feature multiple candidates from each of the larger parties, and this intraparty competition weakens the value of the party label and encourages the development of dynasties, whose members can inherit the bailiwicks of their predecessors and enjoy considerable electoral advantages (Smith, 2012). As a result, members of dynasties have accounted for a sizeable percentage of candidates, TDs, and

\footnotetext{
${ }^{4}$ What we call the informational advantage could more accurately be considered the residual of all non-electoral advantages that legacies enjoy, including information, resources, wealth, and education. We explore some of these potential mechanisms in a later section.

${ }^{5}$ The number of districts in our sample varies from a low of 34 in 1944 to a high of 43 in 2007 and 2011. Apart from three 7-member districts in 1944, all districts elect 3, 4, or 5 members.
} 
cabinet ministers in Ireland (Figure 1). Among all candidates from 1944-2016, 14 percent were legacies of one type or the other. Among elected TDs, the proportion increases to 25 percent. Yet among cabinet ministers, the proportion is even higher: 29 percent, on average, and in some cabinets higher than 40 percent (including the current cabinet of Prime Minister Enda Kenny, at 44 percent). The increase is mostly attributable to more cabinet legacies getting appointed. One minister, Kevin Boland, the son of Gerald Boland (a 13-term Fianna Fáil member and former Minister of Justice), was appointed Minister of Defense after his very first election to the Dáil in 1957.

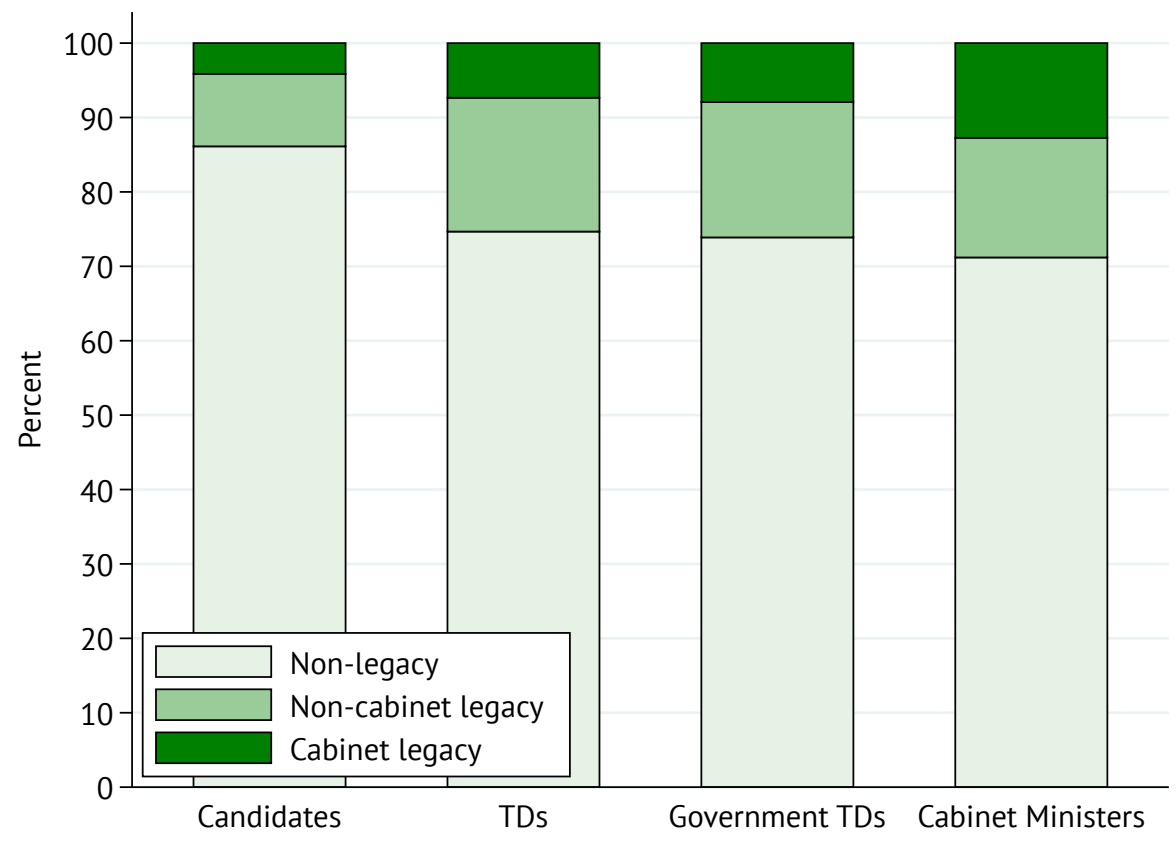

Figure 1: Proportion of legacies among candidates, TDs, government-party TDs, and cabinet ministers in the Republic of Ireland, 1944-2016

Source: The primary sources of the candidate data are Elections Ireland (electionsireland.org), Gallagher (1993), and Gallagher (2009) for elections prior to 2011. Source for 2011 and 2016 elections is The Independent newspaper (online). Ministerial appointment data are from the website of the Department of the Taoiseach (Prime Minister). Data sources for family ties are listed in footnote 9.

Note: Observations pooled across all elections from 1944-2016. Includes by-election candidates and winners. Online Appendix Figure A.1 shows the percentages for each type of legacy over time.

The overrepresentation of cabinet legacies in ministerial positions indicates that, in addition to the well-known legacy advantage in elections, there may also be a legacy advantage in cabinet promotion. However, it is unclear to what extent this advantage stems indirectly from the electoral advantages of legacy versus the less-tangible, though more direct, informational advantage. Are 
cabinet legacies overrepresented in cabinet simply because they are better at getting votes, and thus are more senior and electorally popular, on average, than non-legacies or non-cabinet legacies in their parties? Or do cabinet legacies enjoy an additional advantage owing to their closer ties to party leaders and an established family record in high-level politics?

Our main contribution in this study is to provide a theoretical explanation for a legacy advantage in cabinet promotion that incorporates both the electoral and informational advantages of members of dynasties, and how these may differ depending on the family history of an individual MP. We then empirically test the predictions of this theory with our novel Irish data, first using candidate-level observations to examine the electoral advantages of different legacy types, and then TD-level observations to evaluate the relative influence of the electoral and informational advantages of legacy in cabinet selection decisions.

The results of our analyses reveal that, although cabinet legacies and non-cabinet legacies enjoy equally significant electoral advantages over non-legacies, only cabinet legacies enjoy an advantage in ministerial selection. In other words, the advantage of cabinet legacies in ministerial selection cannot simply be attributed to their greater electoral strength. This finding points to a potential inequality in access to positions of power in parliamentary systems, with broad implications for our understanding of the development of democracy and representative government. After presenting our main results, we explore several other potential mechanisms behind the advantage with variables related to experience, demographics, education, dynasty strength, and party regional strength. Although the observational nature of our data does not allow us to rule out all possible mechanisms, we find that differences in level and place of education between cabinet legacies and other TDs may be an important part of the legacy advantage in cabinet selection. The former hints at potential differences in qualifications, while the latter hints at elite network effects. 


\section{Reaching the Top: Ministerial Selection in Parliamentary Democ-}

\section{racies}

As Bäck, Debus and Dumont (2011, p. 442) note, the question of "who gets which ministerial remits and why?" has traditionally been answered with a party-level variable, focused on the distribution of cabinet seats between parties in the legislature and side-stepping the question of which individuals within parties attain ministerial office. Similarly, intraparty analyses have tended to focus on the allocation of portfolios to groups within parties, such as factions (e.g., Leiserson, 1968; Mershon, 2001; Ono, 2012). In reality, ministerial positions are significant post-election offices filled by individual MPs. Just as parties and candidates compete with each other for elective office, so too must MPs within parties compete for higher positions of power (Andeweg, 2000, Saalfeld, 2000).

The existing literature identifies a number of factors that might influence individual ministerial selection decisions within parties. In an early contribution, Blondel and Thiébault (1991) focus on the personal characteristics and social backgrounds of West European ministers and find that they tend to be older and more highly educated, and tend to have had longer careers within the party than their backbench colleagues. O'Malley (2006) explores the basis for selecting ministers in Ireland through interviews with former party leaders and ministers, and also finds that personal characteristics matter: in particular, prime ministers value "talent, loyalty, experience, tenacity, cleanliness (from corruption) and good personal relations" (O’Malley, 2006, p. 329). His quantitative analysis reveals little evidence of the often assumed geographical dispersion of posts, but does find that ministers tend to display higher levels of education, longer lengths of tenure in parliament, and greater success in previous general elections. In Canada, Kerby (2009) also finds that seniority, gender, level of education, age, and prior ministerial experience help predict who becomes a minister. As in the Irish case, electoral popularity correlates positively with being selected for cabinet —on average, cabinet appointees have a margin of victory of 26 percentage points over runners-up in their districts, compared to 23 percentage points for those governing-party MPs 
who are not appointed. Thus, one commonly shared characteristic of ministers compared to nonministers is that ministers are ex ante electorally successful.

In another recent study, Pekkanen, Nyblade and Krauss (2014) argue that electoral reform in Japan altered the strategies of party leaders in cabinet selection. Under the current mixed system combining single-member districts and proportional representation, electoral competition is less focused on individual candidates (relative to the previous multi-member district system), and more centered on the image of the party leader and platform. As a result, prime ministers have an incentive to pay less attention to factional balancing and routine promotion based on seniority, and instead appoint more policy experts to serve the party's policy goals and more women to help the party appear more diverse.

We seek to contribute to this growing literature on the intraparty determinants of individual ministerial selection by examining whether being a member of a political dynasty creates an advantage for some MPs over others in the race to win a cabinet seat. We distinguish between two potential mechanisms underlying the legacy advantage: an electoral advantage that represents an indirect or mediating effect of legacy, and an informational advantage that we consider a more direct effect of legacy. Importantly, the nature and value of this informational advantage can vary depending on an MP's family history in cabinet.

\section{Further and Faster: The Theoretical Advantages of Legacy}

To understand the advantage of legacy in securing a seat in cabinet, let us first consider the role and preferences of the person who selects members of the cabinet. As Dewan and Hortala-Vallve (2011, p. 610) note, "The prime minister chooses who is promoted to the cabinet and who remains

on the backbenches." We assume that the prime minister makes a deliberate choice in selecting who to appoint, aiming to promote co-partisans who will perform the duties of office most effectivelythose who Laver and Shepsle (1994, p. 302) describe as "ministerable." It is important to appoint the most competent individuals possible since the performance of the government is dependent, at 
least in part, on the performance of individual ministers. As members of the cabinet, ministers are individually responsible for the performance of their ministries, but also represent the public face of the cabinet collectively, both in parliament and in the media. As such, the popularity of the party (or parties) in government is linked to the individual performance and popularity of ministers, and appointing the right (or wrong) ministers can have consequences for a governing party's ability to win votes and seats at election time (Müller and Strøm, 1999). 6

From the perspective of individual MPs, ministerial office is highly desirable. Ministerial office produces for the officeholder the ability to influence policy, and also comes with a number of personal payoffs, including greater status and pecuniary benefits-such as a higher salary, enhanced pensions upon leaving office, and a personal bureaucracy - as well as significant electoral rewards (Martin, 2016). This demand for ministerial office contrasts with the supply of positions. Not every backbencher can become a minister. First, parties arguably need backbenchers in order to conduct ordinary parliamentary business. Second, constitutions often specify a maximum size of cabinet-for example, fifteen ministers according to the Constitution of Ireland. Combining the significant demand for higher office with the under-supply of positions creates a classic, but nevertheless high-stake, principal-agent selection game for the prime minister. Like with voters selecting MPs, the prime minister operates with limited or imperfect information when selecting his or her cabinet.

Voters often rely on cues and shortcuts in making informed choices under limited information (Lupia and McCubbins, 1998). So, too, must the prime minister in selecting her cabinet. The prime minister has some opportunities to observe and learn about would-be ministers: in the party caucus, on the floor of the chamber, in committees, and through public appearances. Such events provide would-be ministers with opportunities to impress the prime minister. As such, the cabinet selection game can be viewed as a game between the prime minister and would-be ministers. Would-be ministers need to signal to the prime minister that they have the qualities necessary to

\footnotetext{
Dewan and Dowding (2005) find that removing an unpopular minister can significantly enhance the popularity of the government.
} 
be a successful minister and thereby contribute to the positive reputation of the prime minister, the party, and government.

While some personal traits that would aid appointment to ministerial office are fixed, many characteristics and skills can be developed and enhanced. As Kerby (2009, p. 602) notes, what scholars of ministerial selection take to be electoral popularity in the district may be a proxy for other less tangible qualities, including “political capital, constituency support, organizational ability, or finesse." Some individual MPs have more charisma or talent than others, but such skills can also be learned and developed over time. On the other hand, some fixed characteristics of an individual MP represent ex ante endowments that may give him or her advantages over peers in developing these skills, or that represent inherently attractive qualities that make him or her more focal to party leaders in appointment decisions. We believe that legacy status may fall into this category of traits.

Because they can often "inherit" the name recognition, financial resources, and political connections of their predecessors, legacy candidates tend to enjoy a considerable electoral advantage over other candidates. For example, Feinstein (2010) estimates that this advantage in the case of the U.S. House of Representatives is roughly 4 percentage points of the vote, about half the size of the well-known incumbency advantage. Smith (2012) and Asako et al. (2015) find even larger electoral advantages in Japan, as does Querubin (2016) in the Philippines. In Ireland, we expect that legacies of both types enjoy a similar electoral advantage:

- (H1) Both non-cabinet legacies and cabinet legacies enjoy an electoral advantage over nonlegacies.

The electoral advantage can insulate legacies from competition and help them to achieve greater seniority in their parties. It may also signal to party leaders that legacies will be more capable, or at the very least more popular, cabinet ministers. Another view is that weak parties, such as those in Ireland, may try to keep electorally powerful members happy by rewarding them with cabinet positions. For example, O’Malley (2006) notes that Irish prime ministers need to be 
cognizant of the personal vote of individual party members, and provide those who are electorally popular with sufficient promise of career promotion to avoid defections or leadership challenges (see also Martin, 2014). In both of these views, the relationship between legacy status and cabinet appointment can be judged to operate via the mediating effect of the electoral advantage. Any legacy advantage in cabinet promotion may at least in part be the result of the greater electoral advantages of legacies, including the ability to reach higher levels of seniority in the party and earn higher vote shares in each election.

However, legacies may also enjoy an informational advantage with regard to promotion that extends beyond their electoral advantages. Dynasties continue to exist in politics, as in family-run businesses, in part because they retain and internally transfer critical information. For example, in considering the backgrounds of members of the U.S. Congress, Parker (1996, p. 88) views legacy status as a decided advantage to both legislators and legislatures, since legacies are often familiar enough with the ways of parliament to hit the ground running on day one: "Family members pass on a number of attributes that are beneficial to a legislature [as they] can act in a tutorial capacity: knowledge is transmitted about the legislative processes (e.g., logrolling) and norms in the legislature (e.g., universalism). ${ }^{\prime 7}$ We see an analogy with the well-established literature on the experience of first-generation college students (students whose parents did not go to university) compared with students whose families have a history of sending their children to university. That literature observes that first-generation college students tend to underperform, at least initially, relative to other students, even controlling for IQ and high school grades (Terenzini et al., 1996).

Sociologists and economists have studied the phenomenon of intergenerational transmission of many human outcome variables_-such as labor market status, class, income, wealth, and criminality. For example, Blau and Duncan (1967) observe high levels of occupational inheritancea situation where an offspring chooses the same career as one of their parents-among independent professionals, family business owners, and farmers. Ganzeboom, Treiman and Ultee (1991, p.

\footnotetext{
${ }^{7}$ An intergenerational transfer of knowledge need not be the exclusive preserve of dynasties. Political networks or machines may be built within a particular cadre of individuals who are not related by blood or marriage. However, machines in Ireland have typically been dynastic in nature (Sacks, 1976).
} 
277) suggest an "intergenerational transmission of socioeconomic advantage" as the likely causal mechanism behind occupational inheritance. Laband and Lentz (1983) argue instead for a rationaleconomic basis to occupational inheritance. For them, following in the career footsteps of a parent is a way to effect a transfer of "intangible wealth." Such intangible assets include "specialized knowledge, goodwill, brand (or name) loyalty, and other types of family-specific capital whose present value cannot be fully captured (realized) by the parent" (Laband and Lentz, 1983, p. 474). In short, these intangibles (that make up what we collectively call the informational advantage) provide a comparative advantage to successors both inside and outside the world of politics.

When it comes to ministerial selection, we expect that this informational advantage will be strongest for legacies whose predecessors served in cabinet. Our core suggestion is that cabinet legacies are more likely to have knowledge of the "rules of the game" in terms of what it takes to become a minister and how to promote those qualities that prime ministers find desirable. Cabinet legacies have often been exposed to the workings of high-level party politics from an early age, and may possess an informational advantage from the inter-generational familiarity with the ways of party politics and ministerial selection. Moreover, a national-level reputation and the knowledge of how the top levels of government work is a characteristic of value to the party leader. As O'Malley (2006, p. 320) writes with regard to cabinet appointments in Ireland, prime ministers "will want to hire a "safe pair of hands.",

Recent work by Pekkanen, Nyblade and Krauss (2014, p. 14) hypothesize that an overrepresentation of cabinet legacies in Japan after its electoral reform may be due to the greater national-level reputations that these MPs enjoy, and the attractiveness of such reputations to party leaders trying to build popular cabinets. ${ }^{8}$ The informational advantage of cabinet legacies may thus help them to move up the party ranks faster than even their peers with equivalent levels of seniority or local-level electoral popularity. In contrast, although non-cabinet legacies may know

\footnotetext{
${ }^{8}$ Similarly, Taniguchi (2008) finds that legacies in Japan were overrepresented in cabinet in 1996 (after the first election following reform), even controlling for seniority. A recent dissertation by Van Coppenolle (2014) also finds that cabinet legacies in the UK are more likely to get promoted to cabinet, though she does not explore the mechanisms underlying the different probabilities.
} 
how to win votes in their districts and thus obtain high levels of seniority, this knowledge does not necessarily translate to the intraparty game of ministerial selection.

In short, knowing the attributes desired of a minister and knowing how to signal that one possesses these attributes may create a competitive informational advantage for cabinet legacies when it comes to moving from the backbenches to cabinet, even beyond the electoral advantages enjoyed by legacies more generally. This discussion leads us to two additional hypotheses to take to our empirical data:

- (H2) To the extent that non-cabinet legacies enjoy an advantage in cabinet selection, it operates primarily through the electoral advantage.

- (H3) Cabinet legacies enjoy an additional advantage in cabinet selection that operates through the informational advantage.

\section{Data and Empirical Strategy}

We use panel data on all candidates who ran for the Irish Dáil between 1944-2016 to test our theoretical predictions about the influence of legacy on ministerial selection decisions and determine the relative contribution of the electoral and informational advantages. Our candidate-level data allow us to accurately investigate the electoral advantages enjoyed by legacies. For our analysis of the legacy advantage in cabinet promotion, we focus on backbench governing-party TDs.

Ireland is an ideal case for our empirical analysis because of the presence of a substantial number of dynasties, the stability of the electoral and party systems over time, the discretion that prime ministers enjoy in choosing their cabinets, and the norm of appointing ministers from among lower house TDs. Upper house (Seanad) members and non-TDs have rarely been appointed; thus, governing-party TDs represent the pool of potential appointees. The governing parties in the 21 terms and 27 cabinets that make up our data sample most often included one of the two main parties_Fianna Fáil or Fine Gael— the latter usually in coalition with Labour. Table 1 lists all of the cabinets and governing parties from 1944-2016. 
Table 1: Cabinets and governing parties in the Republic of Ireland, 1944-2016

\begin{tabular}{lllll}
\hline Dáil & Year & Cabinet & Dates in Office & Governing Parties \\
\hline 12 & 1944 & de Valera 8 & $6 / 9 / 1944-2 / 18 / 1948$ & FF \\
13 & 1948 & Costello 1 & $2 / 18 / 1948-6 / 13 / 1951$ & FG-Lab-NL-CnT-CnP \\
14 & 1951 & de Valera 9 & $6 / 13 / 1951-6 / 2 / 1954$ & FF \\
15 & 1954 & Costello 2 & $6 / 2 / 1954-3 / 20 / 1957$ & FG-Lab-CnT \\
16 & 1957 & de Valera 10 & $3 / 20 / 1957-6 / 23 / 1959$ & FF \\
& & Lemass 1 & $6 / 23 / 1959-10 / 11 / 1961$ & FF \\
17 & 1961 & Lemass 2 & $10 / 11 / 1961-4 / 21 / 1965$ & FF \\
18 & 1965 & Lemass 3 & $4 / 21 / 1965-11 / 10 / 1966$ & FF \\
& & Lynch 1 & $11 / 10 / 1966-7 / 2 / 1969$ & FF \\
19 & 1969 & Lynch 2 & $7 / 2 / 1969-3 / 14 / 1973$ & FF \\
20 & 1973 & Cosgrave & $3 / 14 / 1973-7 / 5 / 1977$ & FG-Lab \\
21 & 1977 & Lynch 3 & $7 / 5 / 1977-12 / 11 / 1979$ & FF \\
& & Haughey 1 & $12 / 11 / 1979-6 / 30 / 1981$ & FF \\
22 & 1981 & Fitzgerald 1 & $6 / 30 / 1981-3 / 9 / 1982$ & FG-Lab \\
23 & $1982 a$ & Haughey 2 & $3 / 9 / 1982-12 / 14 / 1982$ & FF \\
24 & $1982 b$ & Fitzgerald 2 & $12 / 14 / 1982-3 / 10 / 1987$ & FG-Lab \\
25 & 1987 & Haughey 3 & $3 / 10 / 1987-7 / 12 / 1989$ & FF \\
26 & 1989 & Haughey 4 & $7 / 12 / 1989-2 / 11 / 1992$ & FF-PD \\
& & Reynolds 1 & $2 / 11 / 1992-1 / 12 / 1993$ & FF-PD \\
27 & 1992 & Reynolds 2 & $1 / 12 / 1993-12 / 15 / 1994$ & FF-Lab \\
& & Bruton & $712 / 15 / 1994-6 / 26 / 1997$ & FG-Lab-DL \\
28 & 1997 & Ahern 1 & $6 / 26 / 1997-6 / 6 / 2002$ & FF-PD \\
29 & 2002 & Ahern 2 & $6 / 6 / 2002-6 / 14 / 2007$ & FF-PD \\
30 & 2007 & Ahern 3 & $6 / 14 / 2007-5 / 7 / 2008$ & FF-PD-G \\
31 & 2011 & Kowen & $5 / 7 / 2008-3 / 9 / 2011$ & FF-PD-G \\
32 & 2016 & Kenny 2 & $3 / 9 / 2011-5 / 6 / 2016$ & FG-Lab \\
\hline & & $5 / 6 / 2016-$ present & FG-Independents* \\
\hline
\end{tabular}

Note: FF: Fianna Fáil; FG: Fine Gael; Lab: Labour; NL: National Labour; CnT: Clann na Talmhan; CnP: Clann na Poblachta; PD: Progressive Democrats; DL: Democratic Left; G: Greens. Dates recorded as month/day/year. (*) Enda Kenny's second government (2016) was a minority government formed with the support of nine independents, who are considered "governing party" TDs for the purpose of our analysis. 


\section{Family Ties of Candidates and TDs}

Our candidate-level data contain 8,715 observations on 3,721 individuals across 21 general elections and 97 by-elections. Although our sample commences with the 1944 general election, we code the dynastic ties of candidates to former TDs and ministers going as far back as 1918, the year before the meeting of the first Dáil, and a few candidates are even related to pre-Independence Irish MPs who served in the U.K. House of Commons-thus, there is minimal risk of an artificial increase in our measurement of dynasties over time owing to the observability of anterior relatives 9 For elected TDs, our data include detailed biographical information on prior local-level political experience, service in the Seanad, former occupation, place of education, level of education, place of birth, age, and gender.

Of the 3,721 individual candidates in the sample, 274 were legacies (188 non-cabinet legacies; 86 cabinet legacies), and of these, 203 were elected to the Dáil at least once during the time period we study (143 non-cabinet legacies; 60 cabinet legacies). Table 2 details the frequency and percentage of different types of family relations of candidates and TDs, and the number of family generations for elected TDs. For candidates with multiple generations of TDs before them, we use the most immediately preceding relation. The most common family predecessor is a father55 percent of all legacy candidates and TDs followed in their father's footsteps. 10 In terms of generation, 62 percent of legacy TDs were only the second person in their families to serve in

\footnotetext{
${ }^{9}$ The complete candidate-level data contain 11,670 observations on 4,716 individuals across 32 general elections and 131 by-elections held between 1918-2016. We code family ties to former TDs for both elected and unelected candidates. The data were compiled from multiple sources, including the Houses of the Oireachtas Members Database (www.oireachtas.ie), Elections Ireland (electionsireland.org), Gallagher (1993), Gallagher (2009), and newspaper records. Further biographical information was compiled from the Dictionary of Irish Biography (dib.cambridge.org), various editions of almanacs such as the Nealon's Guide, Magill Book, and Thom's Commercial Directory, newspaper reports, candidate websites, and census records. It is possible that some non-obvious relations escaped our coding. However, such obscure relationships would have also likely been obscure to voters and party leaders, and thus less pertinent to the legacy advantage we aim to evaluate.

${ }^{10}$ Several other $n$-th generation candidates also had paternal predecessors but were preceded most proximally by a brother, mother, or other relative. Approximately 85 percent of candidates succeeded their predecessor with no time gap; over 95 percent had a gap of less than ten years. The largest gap between a predecessor and a successor is 33 years.
} 
Table 2: Family relationships and generations Irish legacy candidates and TDs

\begin{tabular}{lrrrr}
\hline & Candidates & \multicolumn{2}{c}{ TDs } \\
Nearest Predecessor & $\mathrm{N}$ & $\%$ & $\mathrm{~N}$ & $\%$ \\
\hline Father & 140 & 51.09 & 111 & 54.68 \\
Father-in-law & 4 & 1.46 & 4 & 1.97 \\
Brother/half-brother & 38 & 13.87 & 23 & 11.33 \\
Grandfather & 4 & 1.46 & 2 & 0.99 \\
Uncle/great uncle & 33 & 12.04 & 28 & 13.79 \\
Mother & 5 & 1.82 & 3 & 1.48 \\
Sister/half-sister & 5 & 1.82 & 2 & 0.99 \\
Aunt/great aunt & 1 & 0.36 & 0 & 0.00 \\
Spouse & 13 & 4.74 & 11 & 5.42 \\
Cousin & 14 & 5.11 & 8 & 3.94 \\
Other relative & 16 & 5.84 & 10 & 4.93 \\
Son & 1 & 0.36 & 1 & 0.49 \\
\hline Total & 274 & 100 & 203 & 100 \\
\hline & & & & \\
\hline Generation & & & $\mathrm{N}$ & $\%$ \\
\hline Second & & & 126 & 62.07 \\
Third & & & 40 & 19.70 \\
Fourth & & & 22 & 10.84 \\
Fifth & & & 6 & 2.96 \\
Sixth & & & 4 & 1.97 \\
Seventh & & & 3 & 1.48 \\
Eighth & & & 1 & 0.49 \\
Ninth & & & 203 & 0.49 \\
\hline Total & & & & 100 \\
\hline
\end{tabular}

Note: The single case in the Son category is Patrick Lenihan, who is the only parent to follow a child (Brian Lenihan, Sr.) into politics. The Other relative category includes in-laws, second cousins, and any case where the exact nature of the relationship could not be determined (e.g., because sources listed the individual only as a "relative." The family that has supplied the most TDs is the O'Higgins dynasty, of which Irish nationalist and founding father Kevin O'Higgins was a member. His brother, Tom O'Higgins, Sr., also served (7th generation), along with his nephews, Tom O'Higgins, Jr. (8th generation), and Michael O'Higgins (9th generation). The other two 7th generation TDs are Louis J. Belton and John Grattan Esmonde. 
parliament. ${ }^{11}$

\section{Research Design}

Our baseline empirical specification is a linear regression of the form:

$$
Y_{i}=\beta_{0}+\beta_{1} \text { Non-cabinet legacy }{ }_{i}+\beta_{2} \text { Cabinet legacy }_{i}+\xi_{i},
$$

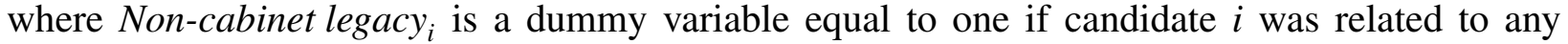
current or former TD or Senator who never served in cabinet, and Cabinet legacy is a dummy variable equal to one if a legacy candidate's predecessor served in a cabinet position. The baseline comparison group is non-legacy candidates and TDs, thus $\beta_{1}$ estimates the average advantage for non-cabinet legacies over non-legacies, and $\beta_{2}$ estimates the average advantage for cabinet legacies over non-legacies. $\xi_{i}$ is an error term. In all specifications, we include robust standard errors clustered at the individual level.

For our candidate-level analysis of the electoral advantage, $Y_{i}$ takes the form of one of two dependent variables. The first, $\operatorname{Win}_{i}$, is a binary outcome variable for whether candidate $i$ won a seat in the election. The second dependent variable, Share of quota $i$, is the share of the Droop quota obtained by the candidate with first preference votes. The Droop quota (Droop, 1881), measured as $\left(\frac{\text { Total valid votes }}{M+1}\right)+1$, is the absolute minimum number of votes that a candidate must earn to guarantee election. For Ireland's multi-member districts, this variable serves to normalize our measure of electoral strength across districts of varying magnitude. In subsequent specifications, we add party-year and district-year fixed effects (i.e., group dummies for each party (district) in each year), and controls for gender and whether the individual was a first-time candidate.

To evaluate the legacy advantage in cabinet selection, our dependent variable $Y_{i}$ takes the

\footnotetext{
${ }^{11}$ Online Appendix Table A.1 gives complete descriptive statistics on the candidate-level variables in our data set, as well as the distribution of parties. Candidates occasionally change party labels, but roughly 41 percent of legacies first ran as Fianna Fáil candidates; 27 percent first ran as Fine Gael, 11 percent as Labour, 7 percent as independents, and the remainder were spread across other minor parties.
} 


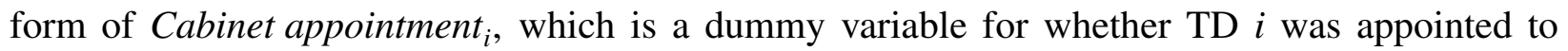
cabinet at any point during the legislative term following the general election. We exclude prime ministers from the sample (as they are the ones selecting ministers), as well as the current Speaker of the Dáil (Ceann Comhairle), who is not eligible for cabinet appointment, and the previous term's Speaker, who is returned to parliament without election 12 Lastly, we exclude opposition TDs (who are not in the pool of potential appointees) and governing-party TDs with previous cabinet experience. We focus on first-time appointments since prior cabinet experience can significantly affect the subsequent electoral advantages of TDs (Martin 2016), as well as the likelihood of reappointment. The final data sample includes 1,477 observations for 728 individual backbench governing-party TDs covering 21 legislative terms and 27 cabinets. Of the 728 individual TDs, 155 were appointed to cabinet, an average of seven each term. The sample includes 117 non-cabinet legacies (16 percent of individuals), 25 of whom were appointed to cabinet; and 49 cabinet legacies (7 percent of individuals), 19 of whom were appointed to cabinet.

It is difficult to identify the direct effect of the informational advantage since legacy status contributes to electoral advantages, which are also likely to increase the probability of cabinet promotion. In other words, any electoral advantages enjoyed by cabinet legacies and non-cabinet legacies can be considered "post-treatment." Our empirical strategy is to first estimate the legacy advantage in cabinet selection without controlling for variables related to the electoral advantage, and then to evaluate whether the estimate of the effect for each type of legacy is affected when these controls are included ${ }^{13}$ As with our candidate-level analysis, we begin with the simple linear

\footnotetext{
${ }^{12}$ Only one prime minister, John A. Costello, did not previously serve in a different cabinet position, though he had served as Attorney General. By tradition, the deputy speaker (Leas-Cheann Comhairle) is selected from among the opposition TDs. Two other TDs, Brian Brady and Cormac Breslin of Fianna Fáil, were returned unopposed in Donegal West in 1944, as was former Speaker Frank Fahy in 1951, so all are dropped from analyses that include the share of the quota as a variable (none were appointed to cabinet). By-election winners (42 observations) are included, as there is no prohibition on their being appointed after the election. In practice, this has happened only once: Hugh Coveney was appointed Minister of Defense in 1994 after winning a by-election. One minister, James Dillon, ran briefly as an independent before re-joining Fine Gael. For our analysis, we code him as Fine Gael.

${ }^{13}$ This is the most straightforward way to evaluate whether the electoral advantage has a mediating effect on cabinet appointment, but is limited in terms of causal identification of the direct effect because the electoral variables introduce post-treatment bias. An alternative approach is to use the linear structural equations model (LSEM) approach described by Baron and Kenny (1986) or the mediation approach described by Imai et al. (2011). However, these approaches are
} 
regression in equation (1) as our baseline specification. In subsequent specifications, we add party and party-year fixed effects, and our mediating variables related to electoral strength.

Our variables for electoral strength include Share of quota in the most recent election, and Number of wins, which is the number of time-t-inclusive legislative terms served. We also include Number of wins ${ }^{2}$ to allow for this relationship to be non-linear. After our main analysis, we further unpack the informational advantage with additional control variables, including prior political experience in the Seanad and local assemblies, prior occupation, gender, age, local birth, level of education, and place of education 14

\section{Results}

We have argued that the overall legacy advantage in cabinet promotion, if it exists, may be related to two potential mechanisms: the electoral advantages of legacy and the informational advantages inherent within dynasties. Before evaluating the legacy advantage in cabinet selection, however, we first use the sample of all candidates to evaluate the electoral advantage enjoyed by both cabinet and non-cabinet legacies over non-legacies.

\section{The Legacy Advantage in Elections}

Table 3 gives the results using $\operatorname{Win}_{i}$ as the dependent variable. In specification (1), we do not include any fixed effects or controls. In specification (2), we add party-year fixed effects. In specification (3), we instead use district-year fixed effects. Specifications (4) and (5) repeat these latter two specifications, but add controls for gender (Female) and whether it was the candidate's

best suited to single-mediator situations and non-categorical explanatory variables.

${ }^{14}$ Our data do not allow us to control for other factors, such as policy expertise, which may lead to cabinet appointment (Hallerberg and Wehner, 2013). Ireland scores low on the appointment of technocrats, and while professional training may explain which minister gets which portfolio (education ministers tend to have previous careers as teachers, for example), no tendency seems to exist between policy background and entry into cabinet. Online Appendix Table A.2 gives complete descriptive statistics on the TD-level variables in our data set, as well as the distribution of parties in the sample. 
Table 3: The electoral advantage of legacy: election result

\begin{tabular}{lrrrrr}
\hline & $(1)$ & $(2)$ & $(3)$ & $(4)$ & $(5)$ \\
\hline Non-cabinet legacy & 0.378 & 0.249 & 0.397 & 0.205 & 0.305 \\
& $(0.025)$ & $(0.026)$ & $(0.027)$ & $(0.024)$ & $(0.026)$ \\
Cabinet legacy & 0.350 & 0.237 & 0.398 & 0.196 & 0.311 \\
& $(0.037)$ & $(0.037)$ & $(0.041)$ & $(0.033)$ & $(0.037)$ \\
Female & & & & -0.057 & -0.055 \\
& & & & $(0.018)$ & $(0.021)$ \\
First-time candidate & & & & -0.330 & -0.401 \\
& & & & $(0.012)$ & $(0.012)$ \\
Constant & 0.335 & 0.352 & 0.331 & 0.496 & 0.509 \\
& $(0.010)$ & $(0.008)$ & $(0.010)$ & $(0.011)$ & $(0.013)$ \\
\hline $\mathrm{N}$ & 8,715 & 8,715 & 8,715 & 8,715 & 8,715 \\
$\mathrm{R}^{2}$ & 0.069 & 0.289 & 0.127 & 0.377 & 0.268 \\
Party-Year FE & No & Yes & No & Yes & No \\
District-Year FE & No & No & Yes & No & Yes \\
\hline
\end{tabular}

Note: Dependent variable is a dummy variable for whether the candidate won a seat. Robust standard errors in parentheses. All coefficients are statistically significant at the .001 level, apart from Female in specifications (4) and (5), which is significant at the .01 level. Results are unaffected if by-elections are excluded (not shown).

first-time running (First-time candidate).

The coefficients on both types of legacy and across all specifications indicate a significant advantage over non-legacies in getting elected. In our baseline specification, the probability of getting elected increases by roughly 38 percentage points for non-cabinet legacies, and 35 percentage points for cabinet legacies. However, post-estimation Wald tests for equality of these coefficients reveal that the difference is not statistically different from zero (and this is also true for all subsequent specifications). The point estimates on both types of legacies drop in specification (2), where we include party-year fixed effects, but still indicate a roughly a 24-percentage-point advantage for both types of legacies. In other words, when compared to non-legacies within the same party, non-cabinet legacies and cabinet legacies are equally more likely to get elected. Specification (3) includes district-year fixed effects, so the estimation is based on differences within electoral district contests. Here, is the effect is even greater (40 percentage points), and still equivalent for both non-cabinet legacies and cabinet legacies. With the controls included in specifications (4) and (5), 
Table 4: The electoral advantage of legacy: share of quota

\begin{tabular}{lrrrrr}
\hline & $(1)$ & $(2)$ & $(3)$ & $(4)$ & $(5)$ \\
\hline Non-cabinet legacy & 0.294 & 0.158 & 0.292 & 0.125 & 0.217 \\
& $(0.021)$ & $(0.020)$ & $(0.020)$ & $(0.019)$ & $(0.019)$ \\
Cabinet legacy & 0.303 & 0.182 & 0.352 & 0.151 & 0.282 \\
& $(0.038)$ & $(0.037)$ & $(0.042)$ & $(0.034)$ & $(0.038)$ \\
Female & & & & -0.052 & -0.047 \\
& & & & $(0.011)$ & $(0.015)$ \\
First-time candidate & & & & -0.250 & -0.322 \\
& & & & $(0.008)$ & $(0.009)$ \\
Constant & 0.451 & 0.470 & 0.450 & 0.580 & 0.594 \\
& $(0.008)$ & $(0.006)$ & $(0.008)$ & $(0.008)$ & $(0.010)$ \\
\hline $\mathrm{N}$ & 8,693 & 8,693 & 8,693 & 8,693 & 8,693 \\
$\mathrm{R}^{2}$ & 0.081 & 0.460 & 0.240 & 0.553 & 0.405 \\
Party-Year FE & No & Yes & No & Yes & No \\
District-Year FE & No & No & Yes & No & Yes \\
\hline
\end{tabular}

Note: Dependent variable is the proportion of the electoral quota reached by the candidate with his or her first preference votes. The number of observations is smaller due to candidates who ran unopposed or who were automatically returned after serving as Speaker. Robust standard errors in parentheses. All coefficients are statistically significant at the .001 level, apart from Female in specification (5), which is significant at the .01 level. Results are unaffected if by-elections are excluded (not shown).

the coefficient estimates drop to between 20 and 30 percentage points..$^{15}$

In Table 4, we show the results of the same set of model specifications using Share of quota ${ }_{i}$ as the dependent variable rather than $\mathrm{Win}_{i}$. The number of observations drops to 8,693 since some candidates are returned unopposed, but the results are largely equivalent to the results using $\operatorname{Win}_{i}$. Again, across all specifications the difference between the estimates for non-cabinet legacies and cabinet legacies is statistically indistinguishable from zero.

In sum, the candidate-level analysis reveals that both types of legacies enjoy significant electoral advantages over non-legacies (in support of H1), and that these electoral advantages are equivalent across types of legacies. This suggests already that any advantage in cabinet selection enjoyed by cabinet legacies over non-cabinet legacies is unlikely to be attributable to their greater electoral strength.

\footnotetext{
${ }^{15}$ Excluding by-elections (not shown) reduces the sample to 8,202 observations (8,180 for quota analysis), but does not significantly affect the results with either dependent variable.
} 


\section{The Legacy Advantage in Cabinet Selection}

We now turn our attention to evaluating the legacy advantage in cabinet selection and how it differs across legacy status. Recall that we expect non-cabinet legacies to enjoy an advantage in cabinet selection only insofar as it operates through the electoral advantage $(\mathrm{H} 2)$. In contrast, we expect cabinet legacies to enjoy an advantage in cabinet selection even after controlling for the electoral advantage (H3). Our preceding analysis already suggests that there should not be a strong effect of Share of quota, as both types of legacies enjoy more-or-less equal advantages in terms of electoral strength. We include this variable for completeness in the analysis to follow, but focus our attention on the differences that remain after controlling for seniority at the time of cabinet formation.

Table 5 gives the results of our regression analysis, where Cabinet appointment is the dependent variable. In specification (1), we present the baseline results with no controls. In specifications (2) and (3), we add party and party-year fixed effects, respectively. In specification (4), we add Number of wins and Number of wins ${ }^{2}$ to control for differences in seniority. Since this specification controls for seniority in the party at the time of cabinet formation without introducing any post-treatment bias related electoral strength, it is our preferred specification. However, we also explore the effect of adding Share of quota in specification (5) in order to evaluate the indirect effect of the electoral advantage.

The results across all specifications indicate a positive and statistically significant relationship between legacy status and cabinet appointment only for cabinet legacies. ${ }^{16}$ Our estimate of the legacy advantage for cabinet legacies suggests an approximately 8-percentage-point greater probability than non-legacies of getting promoted from the backbenches to cabinet. Non-cabinet legacies enjoy no apparent advantage over non-legacies when it comes to cabinet selection, despite

\footnotetext{
${ }^{16}$ Number of wins, Number of wins ${ }^{2}$, and Share of quota are significant at the .001 level in specifications (4)-(5). In specifications (1)-(4), the coefficient on Cabinet legacy is significant at the .05 level. In specification (5), the point estimate drops slighty, but is still significant at the .1 level. We report similar results using the LSEM approach to mediation (Baron and Kenny, 1986) in Online Appendix Table A.3. When we test cabinet legacies against nonlegacies controlling for seniority and including party-year fixed effects, the LSEM approach gives a total effect of .09 for Cabinet legacy, an indirect effect (through Share of quota) of $.05^{*} 0.23=.01$, and thus a direct effect of .08 (i.e., 8 percentage points).
} 
Table 5: The legacy advantage in cabinet selection

\begin{tabular}{lrrrrr}
\hline & \multicolumn{1}{c}{$(1)$} & \multicolumn{1}{c}{$(2)$} & \multicolumn{1}{c}{$(3)$} & \multicolumn{1}{c}{$(4)$} & \multicolumn{1}{c}{$(5)$} \\
\hline Non-cabinet legacy & -0.008 & -0.006 & -0.010 & -0.018 & -0.025 \\
& $(0.020)$ & $(0.019)$ & $(0.019)$ & $(0.020)$ & $(0.019)$ \\
Cabinet legacy & 0.075 & 0.083 & 0.082 & 0.086 & 0.072 \\
& $(0.038)$ & $(0.037)$ & $(0.037)$ & $(0.039)$ & $(0.042)$ \\
Number of wins & & & & 0.065 & 0.050 \\
& & & & $(0.009)$ & $(0.009)$ \\
Number of wins ${ }^{2}$ & & & & -0.005 & -0.004 \\
& & & & $(0.001)$ & $(0.001)$ \\
Share of quota & & & & & 0.234 \\
& & & & & $(0.039)$ \\
Constant & 0.101 & 0.100 & 0.101 & -0.032 & -0.193 \\
& $(0.009)$ & $(0.009)$ & $(0.009)$ & $(0.017)$ & $(0.033)$ \\
\hline N & 1,477 & 1,477 & 1,477 & 1,477 & 1,477 \\
$\mathrm{R}^{2}$ & 0.004 & 0.020 & 0.044 & 0.078 & 0.105 \\
Party FE & No & Yes & No & No & No \\
Party-Year FE & No & No & Yes & Yes & Yes \\
\hline
\end{tabular}

Note: Robust standard errors clustered on individual TD in parentheses. Excluding by-election winners from the sample (not shown) does not affect the results.

enjoying equivalent electoral advantages, as documented in the previous section.

In combination with the candidate-level results for the legacy advantage in elections, we interpret this as evidence that non-cabinet legacies inherit skills and connections that are useful for winning election in their districts, but that these skills may not be valued by party leaders in ministerial selection decisions. Given that the advantage in cabinet selection for cabinet legacies does not operate primarily through the indirect effect of the electoral advantage, there must be something else about cabinet legacies-what we have collectively labeled the informational advantage- that is responsible for the differences in promotion.

\section{Unpacking the Informational Advantage}

If the legacy advantage in cabinet selection is not related to the electoral advantage, what are the underlying mechanisms? It is possible that the residual effect we have labeled the informational 
advantage operates through some other pre-electoral mediating variable. For example, one possibility is that cabinet legacies are more likely than non-cabinet legacies or non-legacies to gain experience in a local assembly or in the Seanad prior to beginning their careers in the Dáil. Once elected to the Dáil, they might be viewed as having more experience than other TDs, and thus more suited for cabinet promotion. Alternatively, cabinet legacies may be more likely to come from professional career backgrounds, such as law and accounting; or simply have higher levels of education and skills than non-cabinet legacies and non-legacies. If this is the case, then the legacy advantage in cabinet selection might not be because prime ministers value cabinet legacies for their reputation or familiarity, but because they value the combination of experience, demographic attributes, or education that happen to also be more prevalent among cabinet legacies. To the extent that these attributes are the result of being a cabinet legacy, it may be through them that cabinet legacies enjoy a greater advantage in cabinet selection.

For all 728 of the individual TDs in our sample, we have complete data on pre-electoral experience in local assemblies and the Seanad, and prior occupation, $\sqrt{17}$ Figure 2 shows the differences across legacy status for these experience-related variables. Notably, cabinet legacies are more likely to have experience in the Seanad prior to their first election to the Dáil, and are also more likely to have a career background in a senior managerial or professional occupation.

We also have complete data on the demographic variables of gender and age ${ }^{18}$ It is important to consider age because, to the extent that legacies tend to enter office at a younger age, they may seem more attractive than other (older) TDs once they gain similar levels of experience in the party. For 691 TDs, we have information on place of birth, and can thus measure whether the TD was born in or around (within the same county) the district where he or she was elected. Figure 3 shows the differences in these variables across legacy status. Legacies of both types are more

\footnotetext{
${ }^{17}$ Local assembly members are either directly elected or co-opted into office when a sitting member resigns or dies. A majority of Senators are elected indirectly in special vocational or university panels; the remainder are appointed by the prime minister.

${ }^{18} \mathrm{We}$ are missing exact age information for 25 TDs. We estimate the age of these TDs based on the average age of first-term TDs in each group of legacy status. This is 43 for non-legacies, 38 for non-cabinet legacies, and 37 for cabinet legacies. Our statistical results are identical if these TDs are excluded from the analysis.
} 
Figure 2: Pre-electoral attributes, by legacy status: experience
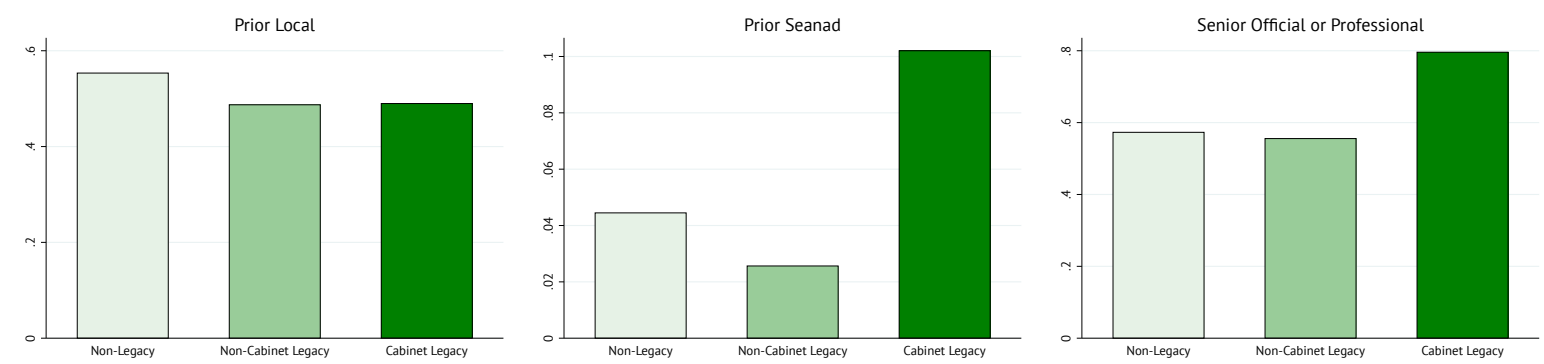

Note: Variables measured as experience prior to first election. Election to a local assembly or the Seanad after serving in the Dáil is not counted. Prior occupation is based on the primary occupation of the TD before his or her first election, and is coded based on the International Standard Classification of Occupations (ISCO) codes from the International Labour Organization. Here we group together ISCO 1 (senior officials and managers) and ISCO 2 (professionals). Y-axis is proportion.

likely to be women, which suggests that dynasties may be a significant pathway into politics for female candidates in an otherwise male-dominated parliament. Legacies also tend to be younger at the time of their first election, and a smaller proportion of cabinet legacies were born in the county where they first won a seat.

Figure 3: Pre-electoral attributes, by legacy status: demographics
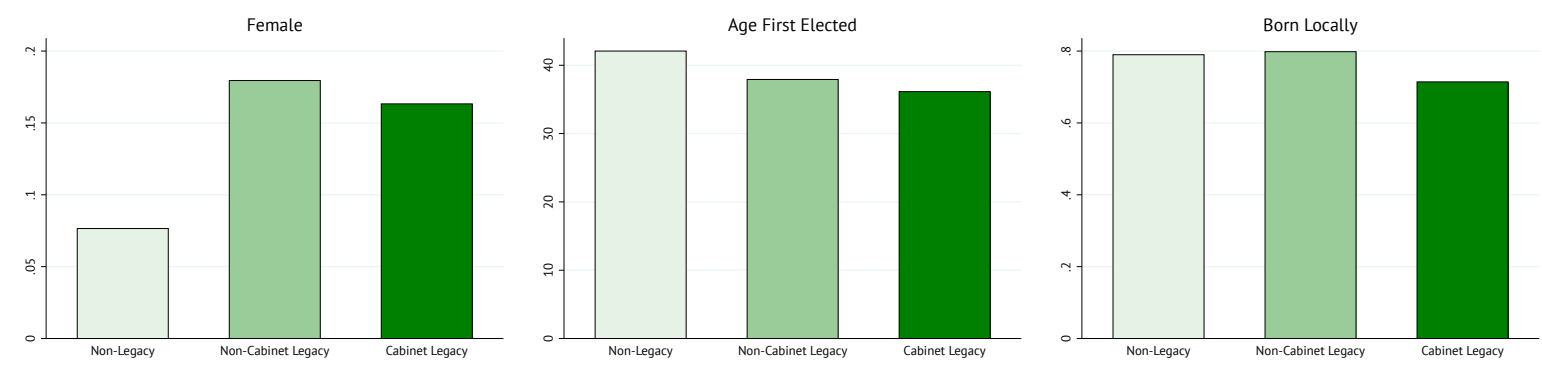

Note: Age at first election is estimated for 25 TDs. Birth data are missing for 37 TDs. Because boundaries sometimes change, a TD is considered to be born locally if he or she was born in the county containing his or her district (e.g., a TD born in Cork County or Dublin County is considered local to all districts within those large counties). Localness is coded at the time of first election. Y-axis is proportion for binary variables; mean for age.

Finally, for a sub-sample of TDs, we have data on place of education, which allow us to explore the effects of level and place of education. Specifically, we measure whether the TD has (1) any post-secondary training or university degree, or (2) a post-graduate degree $(\mathrm{N}=647)$. For 
place of education, we consider whether the TD attended University College Dublin (a common breeding ground for future politicians) $(\mathrm{N}=634)$, and whether the TD's secondary school was a fees-paying (private) institution $(\mathrm{N}=606)$. These latter two variables are related to quality of education, but also hint at network advantages and wealth, respectively. Figure 4 shows the differences in these variables across legacy status. Here, there are large differences in the attributes of cabinet legacies relative to non-cabinet legacies and non-legacies. Nearly 86 percent of cabinet legacies are educated beyond secondary school, compared to only about 60 percent of other TDs. Moreover, roughly 24 percent of cabinet legacies possess a post-graduate degree, compared to just 8 percent of non-cabinet legacies and 9 percent of non-legacies. Cabinet legacies are also more likely to have attended UCD (47 percent) than non-cabinet legacies (20 percent) or non-legacies (20 percent), as well as more likely to have attended a fees-paying secondary school (45 percent, compared to 26 percent and 14 percent, respectively).

Figure 4: Pre-electoral attributes, by legacy status: education
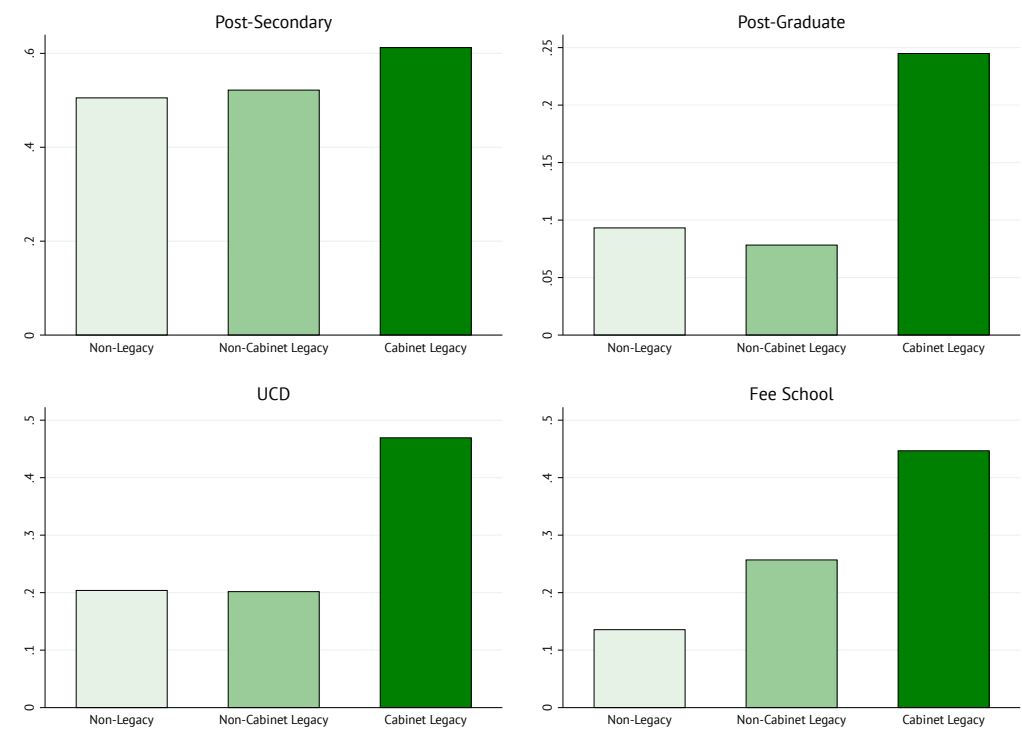

Note: Post-secondary education includes training certificates and higher education diplomas, as well as university degrees. Post-graduate degree includes only M.A., Ph.D., or equivalent. UCD is the University College Dublin. Fee schools are secondary education institutions that require fees (i.e., private schools). Y-axis is proportion.

Figure 5 presents the coefficients and confidence intervals for Cabinet legacy from separate 
regression models conditioning on the inclusion of these variables. All specifications include partyyear fixed effects and controls for seniority (Number of wins and Number of wins ${ }^{2}$ ). Complete results in table format are presented in Online Appendix Tables A.4, A.5, and A.6. The first estimate is the same as in specification (4) from the main analysis in Table 5, and is presented here as the baseline for comparison. Each of the other estimates is from a separate regression with a single additional control variable related to experience: (1) prior experience in a local assembly, (2) prior experience in the Seanad, and (3) categorical dummies for prior occupation (based on ten ISCO occupation codes); demographics: (4) gender (female), (5) age (which we group into five categories: $21-29 ; 30-39 ; 40-49 ; 50-59 ; 60-75)$, and (6) whether the TD was born locally (within the county); or education: (7) categorical dummies for post-secondary training and post-graduate degree (secondary or less is the omitted category), (8) whether the TD attended UCD, and (9) whether the TD attended a fees-paying secondary school.

Among these additional control variables, the measures related to education reduce the point estimate on Cabinet legacy by the greatest amount. Higher levels of education, attendance at the elite UCD, and attendance at a fees-paying secondary school are all estimated to increase the probability of appointment to cabinet ${ }^{19}$ Thus, one of the reasons cabinet legacies are overrepresented in cabinet may simply be because they are better qualified than their peers. However, as all of these variables are also important indicators of network or wealth advantages, which can be considered "post-treatment" effects of being a cabinet legacy, these correlations also suggest that part of the informational advantage operates through elite connections and privilege in Irish society.

Another possible explanation for the advantage enjoyed by cabinet legacies, but not noncabinet legacies, is that cabinet legacies may tend to come from more established dynasties or may enjoy more heuristic cues of the dynasty's reputation—such as sharing the same last name

\footnotetext{
${ }^{19}$ Specifically, TDs with a post-secondary education are 10 percentage points more likely to get appointed to cabinet, conditioning on legacy status and seniority, and TDs with a post-graduate education are 17 percentage points more likely. TDs who attended UCD enjoy an 12 percentage-point advantage, and TDs who attended a fees-paying school enjoy a 6 percentage-point advantage.
} 
Figure 5: Unpacking the informational advantage: experience, demographics, or education?

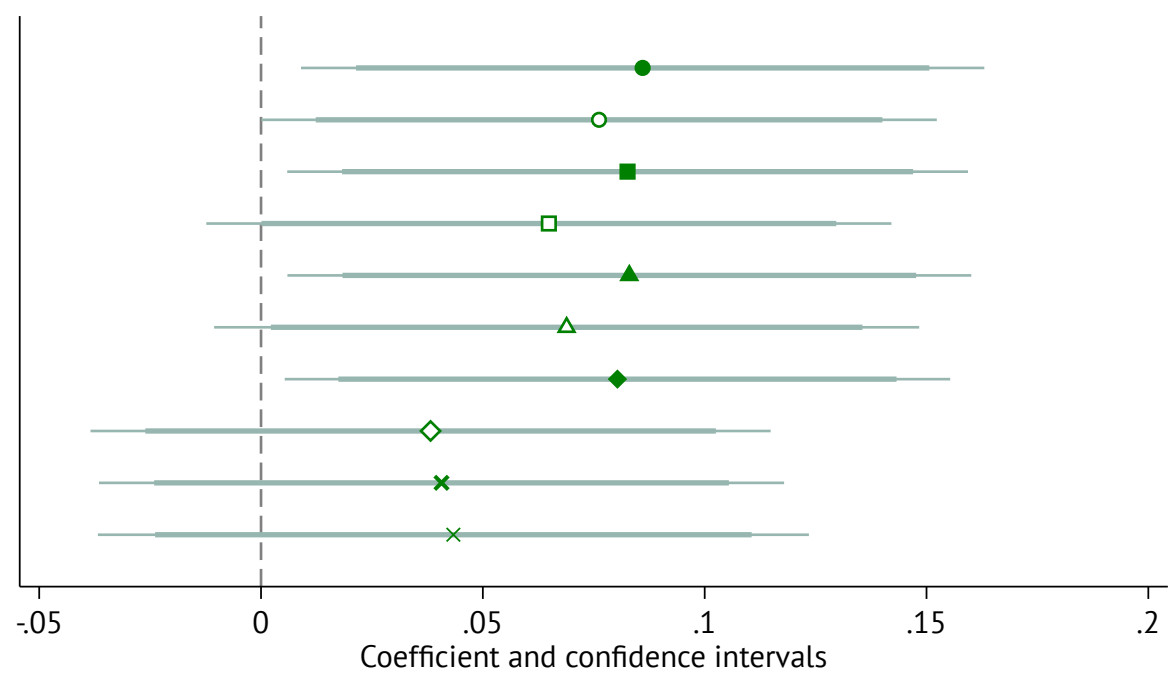

Additional controls included in model:

\begin{tabular}{|c|c|c|c|c|}
\hline - None (baseline) & O Prior local & - Prior Seanad & $\square$ Prior occupation & $\Delta$ Female \\
\hline$\Delta$ Age & Local born & $\diamond$ Education level & × Attended UCD & $\times$ Attended fee school \\
\hline
\end{tabular}

Note: Figure shows the coefficients and confidence intervals for Cabinet legacy from separate models adding controls related to experience, demographics, and education. The thick portion of the confidence interval is $90 \%$; the thin portion is $95 \%$. All models include party-year fixed effects, a dummy for Non-cabinet legacy, and controls for Number of wins and Number of wins ${ }^{2}$. Experience controls include categorical dummies for prior experience in a local assembly, prior experience in the Seanad, and prior occupation (categorical dummies based on ISCO codes). Demographic controls include categorical dummies for gender, age group, and whether the TD was born locally (within the county). Education controls include categorical dummies for level of education (secondary or less, post-secondary training, or post-graduate degree), whether the TD attended UCD, and whether the TD attended a fees-paying secondary school. As not all variables are available for all individuals, some TDs are dropped from the analyses for Local born, Education level, Attended UCD, and Attended fee school. Full results are in Online Appendix Tables A.4, A.5 and A.6. 
or running in the same district. The data do not appear to support this hypothesis (Figure 6). Although cabinet legacies on average have more relatives who have served in the past than noncabinet legacies, they are no more likely to share the same last name, and are actually less likely to run in the same district. Including these variables as controls for the subsample of legacies (noncabinet legacies and cabinet legacies) does not reduce the roughly 10-percentage-point advantage of cabinet legacies over non-cabinet legacies (Table 6), and not one of these variables is itself statistically significant.20

Figure 6: Strength of the dynasty, by legacy status
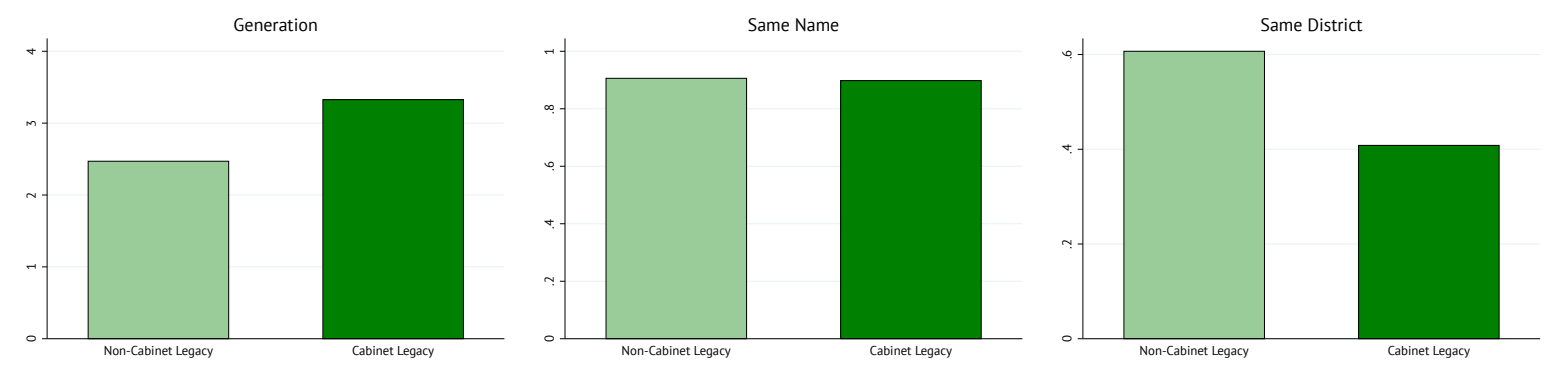

Note: Generation refers to the total number of family members, including the TD, who have served up to that point. Same name and Same district are measured based on whether the TD shared a name or district with any predecessor, not necessarily the most immediate predecessor, or in the case of cabinet legacies with multiple predecessors, the predecessor who served in cabinet. Y-axis is proportion for binary variables; mean for generation.

Finally, an additional possibility to take into account is that there may be some confounding variable $(Z)$ that affects both status as a cabinet legacy $(X)$ and cabinet selection $(Y)$, thus making the correlation between cabinet legacy and cabinet selection we have identified spurious. Put simply, legacy status is not randomly assigned, so the correlation we have shown could indicate a causal relationship, or it could be the result of the omitted $Z$ variable that affects the probability of being a cabinet legacy and the probability of selection into cabinet ${ }^{21}$ The most obvious possibility is variation in the regional strength of candidates' parties.$^{22}$ For example, suppose that party leaders

\footnotetext{
${ }^{20}$ In terms of predecessor relationship, 55 percent of both non-cabinet legacies and cabinet legacies followed their father into politics. The type of predecessor relationship also has no effect on the coefficient for Cabinet legacy.

${ }^{21}$ The existence of this type of confounder is usually referred to as selection bias, or a non-ignorability problem.

${ }^{22}$ An additional possibility, which we are unable to fully test with our data, is that inherent genetic traits, com-
} 
Table 6: Unpacking the informational advantage: strength of the dynasty?

\begin{tabular}{lrrr}
\hline & \multicolumn{1}{c}{$(1)$} & \multicolumn{1}{c}{$(2)$} & \multicolumn{1}{c}{$(3)$} \\
\hline Cabinet legacy & 0.101 & 0.109 & 0.105 \\
& $(0.045)$ & $(0.045)$ & $(0.046)$ \\
Number of wins & 0.085 & 0.085 & 0.084 \\
& $(0.021)$ & $(0.022)$ & $(0.021)$ \\
Number of wins $^{2}$ & -0.008 & -0.008 & -0.008 \\
& $(0.002)$ & $(0.002)$ & $(0.002)$ \\
Generation & 0.008 & & \\
& $(0.017)$ & & \\
Same name & & -0.057 & \\
& & $(0.058)$ & \\
Same district & & & -0.004 \\
& & & $(0.032)$ \\
Constant & -0.086 & -0.016 & -0.061 \\
& $(0.060)$ & $(0.060)$ & $(0.043)$ \\
\hline $\mathrm{N}$ & 378 & 378 & 378 \\
$\mathrm{R}^{2}$ & 0.187 & 0.189 & 0.187 \\
Party-Year FE & Yes & Yes & Yes \\
\hline
\end{tabular}

Note: Robust standard errors clustered on individual TD in parentheses. The comparison group is non-cabinet legacies.

tend to reward TDs from districts or regions of the country where the party is strong. These very same areas may also produce more dynasties since TDs may be more electorally secure.

To evaluate this possibility, we present our main regression specifications with party-regionyear fixed effects in Table 7, with and without controls for seniority. We group districts into regions based on one to three neighboring counties because of district boundary changes across elections in our sample. ${ }^{23}$ The results shown in Table 7 provide no support for party regional strongholds acting as a confounding variable affecting both cabinet legacy status and cabinet selection. Even within the same region, cabinet legacies enjoy a higher probability of cabinet selection than other TDs. The point estimate for Cabinet legacy increases to 10 percentage points and is significant at

petence, or human capital within certain families may lead to higher probabilities that both predecessors and their successors will be drawn to politics and promoted to higher office.

\footnotetext{
${ }^{23}$ For example, boundary changes meant that Cavan and Monaghan counties were sometimes separate districts, but other times a combined district. We code all observations from these districts as being in a combined Cavan-Monaghan "region." This does not affect districts like Louth, Waterford, Wexford, and Wicklow, whose boundaries have always been coterminous with the counties.
} 
Table 7: Unpacking the informational advantage: party strongholds?

\begin{tabular}{lrr}
\hline & \multicolumn{1}{c}{$(1)$} & \multicolumn{1}{c}{$(2)$} \\
\hline Non-cabinet legacy & -0.002 & -0.009 \\
& $(0.024)$ & $(0.026)$ \\
Cabinet legacy & 0.103 & 0.101 \\
& $(0.045)$ & $(0.046)$ \\
Number of wins & & 0.064 \\
& & $(0.012)$ \\
Number of wins ${ }^{2}$ & & -0.005 \\
& & $(0.001)$ \\
Constant & 0.098 & -0.031 \\
& $(0.009)$ & $(0.023)$ \\
\hline $\mathrm{N}$ & 1,477 & 1,477 \\
$\mathrm{R}^{2}$ & 0.321 & 0.343 \\
Party-Region-Year FE & Yes & Yes \\
\hline
\end{tabular}

Note: Robust standard errors clustered on individual TD in parentheses.

the .05 level.

Ultimately, our observational data do not allow us to rule out all potential mechanisms behind what we have called the informational advantage, so these results should be viewed as exploratory, and interpreted accordingly. However, it appears that cabinet legacies' advantage in cabinet selection may in part operate through higher levels of educational qualifications or attendance at Ireland's elite schools. The latter correlation suggests that network effects may be important.

\section{Conclusion}

In parliamentary democracies, effective political power rests with the cabinet. Consequently, understanding which legislative parties enter cabinet is important. Which parties acquire specific ministries has also been the subject of increasing attention, in part reflecting a growing appreciation that individual cabinet ministers are able to set the agenda and control policy production and implementation in their respective portfolios. Constitutionally, however, cabinet posts are typically assigned to individuals rather than to parties. Individual ministers may be loyal agents of their parties (or the coalition agreement), but they may also shirk and pursue a personal agenda, based on 
their own preferences. Despite the vast scholarship on cabinet government, and on agency problems in the parliamentary chain of delegation (Strøm, 2000), relatively little research has explored the question of which individuals become cabinet ministers. All too often, answers to "who gets a cabinet seat?" have started and stopped at the party level, leaving the question of "who is the who?" unanswered.

In this study, we have sought to make a theoretical and empirical contribution to the nascent literatures on individual-level ministerial selection in parliamentary democracies and dynastic politics. Theoretically, we posited that MPs who come from dynasties with a history in cabinet, who we call "cabinet legacies," may possess advantages over non-legacies in promotion from the backbench to the cabinet. We suggested that, in addition to the well-understood electoral advantages of legacy, an established family record in higher office could create an additional informational advantage that would give cabinet legacies an advantage over other backbench MPs in cabinet promotion, including non-cabinet legacies.

Our findings from Ireland indicate that cabinet legacies are decidedly advantaged when it comes to the allocation of a finite number of ministerial positions, and that this advantage is not primarily related to the significantly greater electoral advantages they enjoy. Interestingly, we find that non-cabinet legacies in Ireland are no more likely to get promoted to cabinet than their peers, despite enjoying the same electoral advantages as cabinet legacies. This may be because the multi-member electoral system used in Ireland facilitates electoral security for members of established dynasties, but these electorally safe TDs may not enjoy wider appeal or popularity in (or beyond) their districts. Our exploration of potential mechanisms behind the informational advantage suggests that elite networks developed through private schooling and higher education may be part of the explanation for the informational advantage, though we cannot rule out other possibilities, such as genetics.

We see a number of avenues for future research. First, as we have already hinted, any legacy advantage in ministerial selection may depend on the power of the prime minister or party leader to choose her ministers. The power afforded to party leaders in ministerial selection may 
vary across countries (O’Malley, 2007), and may also be constrained by factors such as stronger norms for seniority rule in promotions. The relative contribution of the electoral and informational advantages of legacy to the overall legacy advantage in cabinet promotion may also vary by other institutional or contextual differences across countries. Future research should therefore evaluate the legacy advantage across different institutional and party organizational constraints.

Second, future research should examine whether cabinet legacies continue to be advantaged even after it has been decided that they will enter cabinet. Within a cabinet, individual portfolios can differ in importance, prestige or salience (Warwick and Druckman, 2001). The office of prime minister or finance minister is likely more of a prize than, for example, being the minister for sports or culture. The possibility of a hierarchy of portfolios begs the question as to whether cabinet ministers who are cabinet legacies are more likely to secure more significant portfolios, and more quickly, or whether the portfolios they secure are similar to those secured by their predecessors.

Third, we have not attempted to evaluate whether legacies or cabinet legacies actually make for more, or less, effective ministers than non-legacies. One measure of performance could relate to their durability (for example, against reshuffles) compared to other cabinet colleagues. Or it could be that the presence of cabinet legacies at the heart of government impacts the quality of public policy and governance. In recent years, dynastic politics have been blamed in the media for producing stale leadership in the face of governance problems, not only in Ireland, but also in democracies with a high presence of dynasties like Japan, India, and the Philippines. In Indonesia, debate over the issue resulted in legislation prohibiting dynasties (later overturned by the Constitutional Court). The main opposition party in Japan, the Democratic Party of Japan, imposed an internal party restriction on dynastic candidate selection prior to the 2009 election, in large part to call negative attention toward the recent prevalence of dynastic prime ministers in the ruling Liberal Democratic Party (Smith, 2013). On the other hand, preliminary research by Besley and ReynalQuerol (2015) suggests that having a dynastic chief political executive might positively impact the rate of economic growth, but only where the leader enjoys significant executive decision-making autonomy. 
If members of dynasties do indeed make for better or worse leaders, then our findings raise potentially profound questions for the design and operation of democratic political systems. Cabinets are at the center of power in parliamentary systems, and the ability of individual cabinet ministers to control policy formation and implementation within their own ministries provides a privileged few with unique opportunities to shape political outcomes (Blondel, 1985, Laver and Shepsle, 1994, 1996; Thies, 2001). For democratic theorists and advocates of electoral and representative democracy, it is thus important to understand why ministerial selection appears to favor a select cadre of party members, and whether this apparent bias in who gets selected actually produces any negative effect on governance. We believe this is an important question for future research, and a natural extension of the growing literature on the impact of the distribution of power in cabinets, not only between parties, but also within.

\section{About the Authors}

Daniel M. Smith is Assistant Professor in the Department of Government at Harvard University. His Ph.D. is from the University of California, San Diego. Recent research on electoral institutions, party organization, and voter behavior appears in the Journal of Politics, Party Politics, and Electoral Studies.

Shane Martin is Reader in Comparative Politics at the Department of Government, University of Essex. He received his Ph.D. from Dublin City University Business School. His research focuses on how electoral incentives shape representatives' preferences, the internal structures of legislatures, and executive oversight. Recent research by him has appeared in Comparative Political Studies, the British Journal of Political Science, Electoral Studies, and Political Research Quarterly. 


\section{References}

Andeweg, Rudy B. 2000. "Ministers as Double Agents? The Delegation Process Between Cabinet and Ministers." European Journal of Political Research 37(3):377-395.

Asako, Yasushi, Takeshi Iida, Tetsuya Matsubayashi and Michiko Ueda. 2015. "Dynastic Politicians: Theory and Evidence from Japan.” Japanese Journal of Political Science 16(1):5-32.

Bäck, Hanna, Marc Debus and Patrick Dumont. 2011. "Who Gets What in Coalition Governments? Predictors of Portfolio Allocation in Parliamentary Democracies.” European Journal of Political Research 50(4):441-478.

Baron, Reuben M. and David A. Kenny. 1986. “The Moderator-Mediator Variable Distinction in Social Psychological Research: Conceptual, Strategic, and Statistical Considerations.” Journal of Personality and Social Psychology 51(6):1173-1182.

Berlinski, Samuel, Torun Dewan and Keith Dowding. 2010. "The Impact of Individual and Collective Performance on Ministerial Tenure.” Journal of Politics 72(2):559-571.

Besley, Timothy and Marta Reynal-Querol. 2015. "The Logic of Hereditary Rule: Theory and Evidence." Working paper. Available at http://www.econ.upf.edu/ reynal/Hereditary_BesleyReynalQuerol_2015.pdf.

Blau, Peter M. and Otis Dudley Duncan. 1967. The American Occupational Structure. New York: John Wiley and Sons.

Blondel, Jean. 1985. Government Ministers in the Contemporary World. London: Sage.

Blondel, Jean and Jean-Louis Thiébault. 1991. The Profession of Government Minister in Western Europe. Basingstoke: Palgrave Macmillan.

Dal Bó, Ernesto, Pedro Dal Bó and Jason Snyder. 2009. "Political Dynasties.” Review of Economic Studies 76(1):115-142. 
Dewan, Torun and David P. Myatt. 2010. “The Declining Talent Pool of Government.” American Journal of Political Science 54(2):267-286.

Dewan, Torun and Keith Dowding. 2005. "The Corrective Effect of Ministerial Resignations on Government Popularity.” American Journal of Political Science 49(1):46-56.

Dewan, Torun and Rafael Hortala-Vallve. 2011. “The Three As of Government Formation: Appointment, Allocation, and Assignment." American Journal of Political Science 55(3):610-627.

Dowding, Keith and Patrick Dumont, eds. 2008. The Selection of Ministers in Europe: Hiring and Firing. Abingdon: Routledge.

Dowding, Keith and Patrick Dumont, eds. 2013. The Selection of Ministers Around the World: A Comparative Study. London: Routledge.

Droop, Henry Richmond. 1881. "On Methods of Electing Representatives." Journal of the Statistical Society of London 44(2):141-196.

Feinstein, Brian D. 2010. "The Dynasty Advantage: Family Ties in Congressional Elections." Legislative Studies Quarterly 25(4):571-598.

Fischer, Jörn, Keith Dowding and Patrick Dumont. 2012. "The Duration and Durability of Cabinet Ministers.” International Political Science Review 33(5):505-519.

Gallagher, Michael. 1993. Irish Elections 1922-44: Results and Analysis. Dublin: PSAI Press.

Gallagher, Michael. 2009. Irish Elections 1948-1977: Results and Analysis. New York: Routledge and the Political Studies Association of Ireland.

Ganzeboom, Harry B. G., Donald J. Treiman and Wout Ultee. 1991. “Comparative Intergenerational Stratification Research: Three Generations and Beyond." Annual Review of Sociology $17: 277-302$. 
Hallerberg, Mark and Joachim Wehner. 2013. "The Technical Competence of Economic PolicyMakers in Developed Democracies." Available at SSRN: http://ssrn.com/abstract=2191490 or http://dx.doi.org/10.2139/ssrn.2191490.

Huber, John D. and Cecilia Martinez-Gallardo. 2008. "Replacing Cabinet Ministers: Patterns of Ministerial Stability in Parliamentary Democracies." American Political Science Review 102(2):169-180.

Imai, Kosuke, Luke Keele, Dustin Tingley and Teppei Yamamoto. 2011. "Unpacking the Black Box of Causality: Learning about Causal Mechanisms from Experimental and Observational Studies.” American Political Science Review 105(4):765-789.

Indridason, Indridi and Christopher Kam. 2008. "Cabinet Reshuffles and Ministerial Drift.” British Journal of Political Science 38(4):621-656.

Ishibashi, Michihiro and Steven R. Reed. 1992. "Second-Generation Diet Members and Democracy in Japan: Hereditary Seats." Asian Survey 32(4):366-379.

Kerby, Matthew. 2009. "Worth the Wait: Determinants of Ministerial Appointment in Canada, 1935-2008.” Canadian Journal of Political Science 42(3):593-611.

Laband, David N. and Bernard F. Lentz. 1983. "Like Father, like Son: Toward an Economic Theory of Occupational Following." Southern Economic Journal 50(2):474-493.

Laband, David N. and Bernard F. Lentz. 1985. "Favorite Sons: Intergenerational Wealth Transfers Among Politicians.” Economic Inquiry 23(3):395-414.

Laver, Michael and Kenneth A. Shepsle. 1996. Making and Breaking Governments. Cambridge: Cambridge University Press.

Laver, Michael and Kenneth A. Shepsle, eds. 1994. Cabinet Ministers and Parliamentary Government. Cambridge: Cambridge University Press. 
Laver, Michael and Norman Schofield. 1998. Multiparty Government: The Politics of Coalition in Europe. Ann Arbor: University of Michigan Press.

Leiserson, Michael. 1968. "Factions and Coalitions in One-Party Japan: An Interpretation Based on the Theory of Games.” The American Political Science Review 62(3):770-787.

Lupia, Arthur and Mathew D. McCubbins. 1998. The Democratic Dilemma: Can Citizens Learn What They Need to Know? Cambridge: Cambridge University Press.

Martin, Shane. 2014. “Why Electoral Systems Don’t Always Matter: The Impact of 'Mega-seats’ on Legislative Behaviour in Ireland." Party Politics 20(3):467-479.

Martin, Shane. 2016. "Policy, Office, and Votes: The Electoral Value of Ministerial Office.” British Journal of Political Science 46(2):281-296.

Mershon, Carol. 2001. “Contending Models of Portfolio Allocation and Office Payoffs to Party Factions: Italy, 1963-79.” American Journal of Political Science 45(2):277-293.

Müller, Wolfgang C. and Kaare Strøm, eds. 1999. Policy, Office, or Votes? How Political Parties in Western Europe Make Hard Decisions. Cambridge: Cambridge University Press.

O’Malley, Eoin. 2006. “Ministerial Selection in Ireland: Limited Choice in a Political Village." Irish Political Studies 21(3):319-336.

O’Malley, Eoin. 2007. “The Power of Prime Ministers: Results of an Expert Survey.” International Political Science Review 28(1):7-27.

Ono, Yoshikuni. 2012. "Portfolio Allocation as Leadership Strategy: Intraparty Bargaining in Japan.” American Journal of Political Science 56(3):553-567.

Parker, Glenn R. 1996. Congress and the Rent-Seeking Society. Ann Arbor: University of Michigan Press. 
Pekkanen, Robert J., Benjamin Nyblade and Ellis S. Krauss. 2014. "The Logic of Ministerial Selection: Electoral System and Cabinet Appointments in Japan.” Social Science Japan Journal 17(1):3-22.

Querubin, Pablo. 2016. "Family and Politics: Dynastic Persistence in the Philippines." Quarterly Journal of Political Science, forthcoming. Available at https://sites.google.com/site/pabloquerubin/research .

Saalfeld, Thomas. 2000. "Members of Parliament and Governments in Western Europe: Agency Relations and Problems of Oversight.” European Journal of Political Research 37(3):353-376.

Sacks, Paul M. 1976. Donegal Mafia: An Irish Political Machine. New Haven, CT: Yale University Press.

Smith, Daniel M. 2012. Succeeding in Politics: Dynasties in Democracies PhD thesis University of California, San Diego. Available at http://escholarship.org/uc/item/1dv7f7bb.

Smith, Daniel M. 2013. Candidate Recruitment for the 2012 Election: New Parties, New Methods... Same Old Pool of Candidates? In Japan Decides 2012: The Japanese General Election, ed. Robert Pekkanen, Steven R. Reed and Ethan Scheiner. New York: Palgrave Macmillan pp. 101-122.

Strøm, Kaare. 1997. "Rules, reasons, and routines: Legislative roles in parliamentary democracies." Journal of Legislative Studies 3:155-174.

Strøm, Kaare. 2000. "Delegation and Accountability in Parliamentary Democracies." European Journal of Political Research 37(3):261-290.

Strøm, Kaare, Wolfgang C. Müller and Torbjörn Bergman, eds. 2003. Delegation and Accountability in Parliamentary Democracies. Oxford: Oxford University Press.

Taniguchi, Naoko. 2008. Keeping it in the Family: Hereditary Politics and Democracy in Japan. 
In Democratic Reform in Japan: Assessing the Impact, ed. Sherry L. Martin and Gill Steel. Boulder, CO: Lynne Rienner Publishers pp. 65-80.

Terenzini, Patrick T., Leonard Springer, Patricia M. Yaeger, Ernest T. Pascarella and Amaury Nora. 1996. "First-generation College Students: Characteristics, Experiences, and Cognitive Development." Research in Higher Education 37(1):1-22.

Thies, Michael. 2001. "Keeping Tabs on Partners: The Logic of Delegation in Coalition Governments." American Journal of Political Science 45(3):580-598.

Van Coppenolle, Brenda. 2014. Political Dynasties and Elections PhD thesis London School of Economics. Available at etheses.lse.ac.uk/883/.

Warwick, Paul V. and James N. Druckman. 2001. "Portfolio Salience and the Proportionality of Payoffs in Coalition Governments.” British Journal of Political Science 38:627-649. 


\section{Appendix}

Figure A.1: Proportion of candidates, TDs, government-party TDs, and cabinet ministers in the Republic of Ireland, by legacy status, 1944-2016
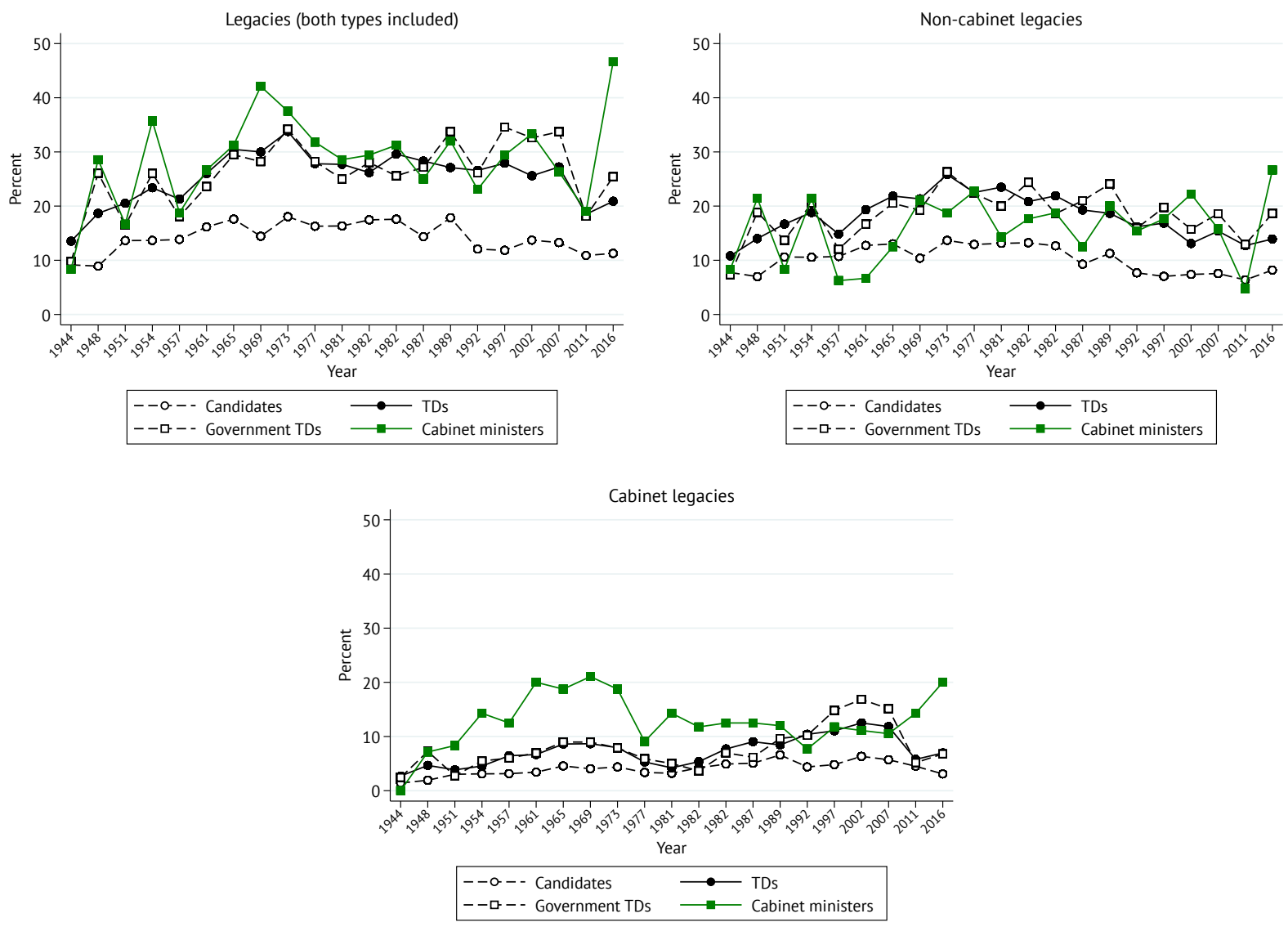

Note: Candidate and TD samples include by-election candidates and winners. Cabinet minister sample excludes nonTD cabinet ministers, and combines all cabinets formed during the term. The primary sources of the candidate data are Elections Ireland (electionsireland.org), Gallagher (1993), and Gallagher (2009) for elections prior to 2011. Source for 2011 and 2016 elections is The Independent newspaper (online). Ministerial appointment data are from the website of the Taoiseach (Prime Minister). Data sources for family ties are listed in footnote 9. 
Table A.1: Descriptive statistics of the data sample: candidates

\begin{tabular}{llcccc}
\hline Variable & Obs. & Mean & Std. Dev. & Min. & Max. \\
\hline Win (DV1) & 8,715 & 0.3860 & 0.4869 & 0 & 1 \\
Share of quota (DV2) & 8,693 & 0.4927 & 0.3608 & 0 & 2.5 \\
Non-cabinet legacy & 8,715 & 0.0974 & 0.2965 & 0 & 1 \\
Cabinet legacy & 8,715 & 0.0414 & 0.1993 & 0 & 1 \\
Female & 8,715 & 0.1138 & 0.3176 & 0 & 1 \\
First-time candidate & 8,715 & 0.3980 & 0.4895 & 0 & 1 \\
\hline & & & & & \\
Party name & Number & Percent & & & \\
\hline Fianna Fáil & 2,500 & 28.69 & & & \\
Fine Gael & 2,112 & 24.23 & & \\
Labour & 1,044 & 11.98 & & \\
Sinn Féin & 397 & 4.56 & & \\
Progressive Democrats & 196 & 2.25 & & \\
Green Party & 237 & 2.72 & & \\
Democratic Left & 38 & 0.44 & & \\
Christian Solidarity & 55 & 0.63 & & \\
Independents & 1,473 & 16.90 & & \\
Indep. Labour/National Labour & 24 & 0.28 & & \\
Workers' Party & 138 & 1.58 & & \\
Socialist & 27 & 0.31 & & \\
People Before Profit & 37 & 0.42 & & \\
New Vision & 20 & 0.23 & & \\
Clann na Poblachta & 173 & 1.99 & & \\
Clann na Talmhan & 66 & 0.76 & & \\
Other minor parties & 178 & 2.04 & & \\
\hline Total & $\mathbf{8 , 1 7 5}$ & $\mathbf{1 0 0}$ & & \\
\hline
\end{tabular}

Note: Sample includes by-election candidates. The number of observations for Share of the quota is lower due to unopposed candidates and former Speakers (Cinn Chomhairle), who are returned automatically. 
Table A.2: Descriptive statistics of the data sample: backbench governing-party TDs

\begin{tabular}{|c|c|c|c|c|c|}
\hline Variable & Obs. & Mean & Std. Dev. & Min. & Max. \\
\hline Cabinet appointment & 1,477 & 0.10 & 0.31 & 0 & 1 \\
\hline Non-cabinet legacy & 1,477 & 0.18 & 0.39 & 0 & 1 \\
\hline Cabinet legacy & 1,477 & 0.07 & 0.26 & 0 & 1 \\
\hline Number of wins & 1,477 & 3.31 & 2.49 & 1 & 15 \\
\hline Share of quota & 1,474 & 0.83 & 0.24 & 0.08 & 2.05 \\
\hline Prior local assembly experience & 1,477 & 0.55 & 0.50 & 0 & 1 \\
\hline Prior Seanad experience & 1,477 & 0.04 & 0.19 & 0 & 1 \\
\hline \multicolumn{6}{|l|}{ ISCO occupation code: } \\
\hline $1=$ Senior officials, managers & 1,477 & 0.16 & 0.37 & 0 & 1 \\
\hline $2=$ Professionals & 1,477 & 0.40 & 0.49 & 0 & 1 \\
\hline $3=$ Technicians, associate professionals & 1,477 & 0.12 & 0.32 & 0 & 1 \\
\hline $4=$ Clerks & 1,477 & 0.02 & 0.15 & 0 & 1 \\
\hline $5=$ Service workers, shop workers & 1,477 & 0.07 & 0.25 & 0 & 1 \\
\hline $6=$ Skilled agricultural, fishery workers & 1,477 & 0.17 & 0.38 & 0 & 1 \\
\hline $7=$ Craft and related trades workers & 1,477 & 0.04 & 0.20 & 0 & 1 \\
\hline $8=$ Machine operators, assemblers & 1,477 & 0.01 & 0.07 & 0 & 1 \\
\hline $9=$ Elementary occupations & 1,477 & 0.01 & 0.07 & 0 & 1 \\
\hline $10=$ Military $/$ IRA & 1,477 & 0.01 & 0.08 & 0 & 1 \\
\hline Female & 1,477 & 0.08 & 0.28 & 0 & 1 \\
\hline Age & 1,477 & 47.25 & 10.70 & 21 & 75 \\
\hline Local born & 1,424 & 0.80 & 0.40 & 0 & 1 \\
\hline Post-secondary training or degree (only) & 1,345 & 0.50 & 0.50 & 0 & 1 \\
\hline Post-graduate degree & 1,345 & 0.09 & 0.28 & 0 & 1 \\
\hline Attended UCD & 1,326 & 0.22 & 0.42 & 0 & 1 \\
\hline Attended fees-paying secondary school & 1,279 & 0.18 & 0.39 & 0 & 1 \\
\hline Party name & Number & Percent & & & \\
\hline Fianna Fáil & 882 & 59.72 & & & \\
\hline Fine Gael & 399 & 27.01 & & & \\
\hline Labour & 140 & 9.48 & & & \\
\hline Progressive Democrats & 14 & 0.95 & & & \\
\hline Greens & 5 & 0.34 & & & \\
\hline Democratic Left & 6 & 0.41 & & & \\
\hline Independent & 8 & 0.54 & & & \\
\hline National Labour & 5 & 0.34 & & & \\
\hline Clann na Poblachta & 10 & 0.68 & & & \\
\hline Clann na Talmhan & 8 & 0.54 & & & \\
\hline Total & 1,477 & 100 & & & \\
\hline
\end{tabular}

Note: Sample excludes Prime Minister, Speaker (Ceann Comhairle), and TDs with previous cabinet experience. Includes by-election winners. The number of observations for Share of the quota is lower due to unopposed candidates and former Cinn Chomhairle, who are returned automatically. 
Table A.3: The direct and indirect effects of being a cabinet legacy: LSEM approach

\begin{tabular}{lrrr}
\hline DV: & $\begin{array}{r}\text { Cabinet } \\
\text { appt. }\end{array}$ & $\begin{array}{r}\text { Share of } \\
\text { quota }\end{array}$ & $\begin{array}{r}\text { Cabinet } \\
\text { appt. }\end{array}$ \\
\hline Cabinet legacy & 0.090 & 0.054 & 0.077 \\
& $(0.039)$ & $(0.039)$ & $(0.042)$ \\
Number of wins & 0.064 & 0.066 & 0.050 \\
& $(0.009)$ & $(0.009)$ & $(0.009)$ \\
Number of wins ${ }^{2}$ & -0.005 & -0.005 & -0.004 \\
& $(0.001)$ & $(0.001)$ & $(0.001)$ \\
Share of quota & & & 0.231 \\
& & & $(0.039)$ \\
Constant & -0.035 & 0.690 & -0.195 \\
& $(0.016)$ & $(0.017)$ & $(0.033)$ \\
\hline N & 1,477 & 1,474 & 1,474 \\
$\mathrm{R}^{2}$ & 0.077 & 0.155 & 0.104 \\
Party-Year FE & Yes & Yes & Yes \\
\hline
\end{tabular}

Note: Robust standard errors clustered on individual TD in parentheses. Non-cabinet legacies are excluded, so the comparison is cabinet legacies to non-legacies. The total effect $(c)$ is the coefficient on Cabinet legacy in the first column $=.09$. The indirect effect $(a b=.01)$ is the product of the coefficient on Cabinet legacy in the second column $(a=.05)$ and the coefficient on Share of quota in the third column $(b=.23)$. The direct effect $\left(c^{\prime}\right)$ is equal to $c-a b=$ .08 . 
Table A.4: The legacy advantage conditioning on pre-electoral attributes (1): experience

\begin{tabular}{|c|c|c|c|c|}
\hline & (1) & (2) & (3) & (4) \\
\hline \multirow[t]{2}{*}{ Non-cabinet legacy } & -0.018 & -0.026 & -0.016 & -0.020 \\
\hline & $(0.020)$ & $(0.020)$ & $(0.020)$ & $(0.020)$ \\
\hline \multirow[t]{2}{*}{ Cabinet legacy } & 0.086 & 0.076 & 0.083 & 0.065 \\
\hline & $(0.039)$ & $(0.039)$ & $(0.039)$ & $(0.039)$ \\
\hline \multirow[t]{2}{*}{ Number of wins } & 0.065 & 0.063 & 0.065 & 0.070 \\
\hline & $(0.009)$ & $(0.009)$ & $(0.009)$ & $(0.010)$ \\
\hline \multirow[t]{2}{*}{ Number of wins ${ }^{2}$} & -0.005 & -0.005 & -0.005 & -0.005 \\
\hline & $(0.001)$ & $(0.001)$ & $(0.001)$ & $(0.001)$ \\
\hline Prior local assembly experience & & $\begin{array}{r}-0.070 \\
(0.017)\end{array}$ & & \\
\hline Prior Seanad experience & & & $\begin{array}{r}0.070 \\
(0.055)\end{array}$ & \\
\hline ISCO-2 = Professionals & & & & $\begin{array}{r}0.069 \\
(0.026)\end{array}$ \\
\hline ISCO-3 = Technicians & & & & $\begin{array}{c}-0.022 \\
(0.029)\end{array}$ \\
\hline ISCO-4 = Clerks & & & & $\begin{array}{r}-0.013 \\
(0.049)\end{array}$ \\
\hline ISCO-5 = Service workers & & & & $\begin{array}{r}-0.066 \\
(0.029)\end{array}$ \\
\hline ISCO-6 = Agricultural, fishery & & & & $\begin{array}{r}-0.040 \\
(0.027)\end{array}$ \\
\hline ISCO-7 = Craft and trades & & & & $\begin{array}{r}-0.057 \\
(0.040)\end{array}$ \\
\hline ISCO-8 = Machine operators & & & & $\begin{array}{r}0.071 \\
(0.118)\end{array}$ \\
\hline ISCO-9 = Elementary occupations & & & & $\begin{array}{c}-0.065 \\
(0.046)\end{array}$ \\
\hline ISCO-10 = Military/IRA & & & & $\begin{array}{r}-0.023 \\
(0.100)\end{array}$ \\
\hline Constant & $\begin{array}{r}-0.032 \\
(0.017)\end{array}$ & $\begin{array}{r}0.012 \\
(0.019)\end{array}$ & $\begin{array}{r}-0.036 \\
(0.017)\end{array}$ & $\begin{array}{r}-0.054 \\
(0.028)\end{array}$ \\
\hline $\mathrm{N}$ & 1,477 & 1,477 & 1,477 & 1,477 \\
\hline $\mathrm{R}^{2}$ & 0.078 & 0.089 & 0.080 & 0.103 \\
\hline Party-Year FE & Yes & Yes & Yes & Yes \\
\hline
\end{tabular}

Note: Robust standard errors clustered on individual TD in parentheses. Experience controls include categorical dummies for prior experience (i.e., before being elected to the Dáil) in a local assembly, prior experience in the Seanad, and prior occupation (baseline category is ISCO $1=$ Senior officials and managers). 
Table A.5: The legacy advantage conditioning on pre-electoral attributes (2): demographics

\begin{tabular}{lrrr}
\hline & \multicolumn{1}{c}{$(1)$} & \multicolumn{1}{c}{$(2)$} & \multicolumn{1}{c}{$(3)$} \\
\hline Non-cabinet legacy & -0.023 & -0.033 & -0.021 \\
& $(0.020)$ & $(0.020)$ & $(0.021)$ \\
Cabinet legacy & 0.083 & 0.069 & 0.080 \\
& $(0.039)$ & $(0.040)$ & $(0.038)$ \\
Number of wins & 0.065 & 0.074 & 0.067 \\
& $(0.009)$ & $(0.010)$ & $(0.010)$ \\
Number of wins ${ }^{2}$ & -0.005 & -0.005 & -0.005 \\
& $(0.001)$ & $(0.001)$ & $(0.001)$ \\
Female & 0.039 & & \\
& $(0.030)$ & & \\
Age 30-39 & & 0.059 & \\
& & $(0.028)$ & \\
Age 40-49 & & 0.043 & \\
& & $(0.028)$ & \\
Age 50-59 & & -0.002 & \\
& & $(0.030)$ & \\
Age 60 and older & & -0.098 & \\
& & $(0.032)$ & \\
Local born & & & -0.051 \\
& & & $(0.023)$ \\
Constant & -0.036 & -0.071 & 0.009 \\
& $(0.017)$ & $(0.026)$ & $(0.025)$ \\
\hline N & 1,477 & 1,477 & 1,424 \\
$\mathrm{R}^{2}$ & 0.079 & 0.098 & 0.083 \\
Party-Year FE & Yes & Yes & Yes \\
\hline
\end{tabular}

Note: Robust standard errors clustered on individual TD in parentheses. Demographic controls include categorical dummies for gender, age group (baseline category is Age 21-29), and whether the TD was born locally (within the county). 
Table A.6: The legacy advantage conditioning on pre-electoral attributes (3): education

\begin{tabular}{lrrr}
\hline & \multicolumn{1}{c}{$(1)$} & \multicolumn{1}{c}{$(2)$} & \multicolumn{1}{c}{$(3)$} \\
\hline Non-cabinet legacy & -0.040 & -0.035 & -0.040 \\
& $(0.021)$ & $(0.021)$ & $(0.023)$ \\
Cabinet legacy & 0.038 & 0.041 & 0.043 \\
& $(0.039)$ & $(0.039)$ & $(0.041)$ \\
Number of wins & 0.075 & 0.074 & 0.074 \\
& $(0.010)$ & $(0.010)$ & $(0.010)$ \\
Number of wins ${ }^{2}$ & -0.005 & -0.005 & -0.005 \\
& $(0.001)$ & $(0.001)$ & $(0.001)$ \\
Post-secondary training or degree (only) & 0.104 & & \\
& $(0.018)$ & & \\
Post-graduate degree & 0.174 & & \\
& $(0.041)$ & & \\
Attended UCD & & 0.116 & \\
& & $(0.025)$ & \\
Attended fees-paying secondary school & & & 0.057 \\
& & & $(0.027)$ \\
Constant & -0.106 & -0.058 & -0.040 \\
& $(0.023)$ & $(0.020)$ & $(0.020)$ \\
\hline $\mathrm{N}$ & 1,345 & 1,326 & 1,279 \\
$\mathrm{R}^{2}$ & 0.113 & 0.107 & 0.092 \\
Party-Year FE & Yes & Yes & Yes \\
\hline
\end{tabular}

Note: Robust standard errors clustered on individual TD in parentheses. Education controls include categorical variables for level of education (baseline category is secondary or less), whether the TD attended the University College Dublin (UCD), and whether the TD attended a fees-paying secondary school (a private institution). 